University for Business and Technology in Kosovo

UBT Knowledge Center

Theses and Dissertations

Student Work

Fall $10-2020$

\title{
Teknologjia e përpunimit të mishit dhe sallameve
}

\author{
Vegim Dedinca \\ University for Business and Technology - UBT
}

Follow this and additional works at: https://knowledgecenter.ubt-uni.net/etd

Part of the Food Science Commons

\section{Recommended Citation}

Dedinca, Vegim, "Teknologjia e përpunimit të mishit dhe sallameve" (2020). Theses and Dissertations. 17. https://knowledgecenter.ubt-uni.net/etd/17

This Thesis is brought to you for free and open access by the Student Work at UBT Knowledge Center. It has been accepted for inclusion in Theses and Dissertations by an authorized administrator of UBT Knowledge Center. For more information, please contact knowledge.center@ubt-uni.net. 


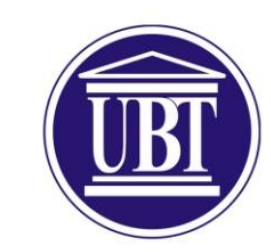

Kolegji UBT

Fakulteti i Shkencave të Ushqimit dhe Bioteknologjisë

\section{TEKNOLOGJIA E PËRPUNIMIT TË MISHIT DHE SALLAMAVE \\ Shkalla Bachelor}

Vegim Dedinca

Prishtinë/ Tetor/ 2019 


\title{
UB1
}

Kolegji UBT

Fakulteti i Shkencave të Ushqimit dhe Bioteknologjisë

\author{
Punim Diplome
}

Viti akademik 2016 - 2017

\section{Vegim Dedinca \\ TEKNOLOGJIA E PËRPUNIMIT TË MISHIT DHE SALLAMAVE \\ Mentori: Xhavit Bytyçi}

Tetor/ 2019

Ky Punim është përpiluar dhe dorëzuar në përmbushjen e kërkesave të pjesshme për Shkallën Bachelor 


\section{ABSTAKT}

Teknologjia e përpunimit të mishit në kuadër të saj edhe të sallamave ka patur një zhvillim të hovshëm, sidomos në dekadën e fundit në Kosovë dhe që ka rezultuar me ngritjen e një numri jo të vogël të fabrikave apo kompanive të perpunimit të mishit, ndër të cilat është edhe kompania SHPK "Sole", të cilat zhvillojnë ativitetin e tyre në objekte të veçanta, me paisje dhe aparatura të veçanta, procedura të veçanta dhe duke respektuar Kodeksin alimentar ndërkombetar dhe standardet ligjore vendore të cilat i rregullojnë këto çeshtje.

Qellimi i këtij hulumtimit është që të verifikohet zbatueshmeria e procedurave të teknologjisë së prodhimit të sallamave si dhe verifikimi i aplikimit të standardeve ligjore e që kanë të bëjnë me kualitetin e sallamave të prodhuara dhe këtë verifikim e kemi realizuar përmes analizave laboratorike për treguesit e cilësisë (analizat fiziko- kimike) dhe treguesëve të sigurisë ( analizave mikrobiologjike) përmes dërgimit të dy mostrave: parizer pule 400 gr dhe parizer viçi 400 gr në laboratorët testues të Institutit Kombërtar të Shëndetësisë Publike të Kosovës, gjatë muajit Shtator të vitit 2019.

Për sa i përket zbatueshmërisë së procedurave teknologjike për prodhimin e sallamave, kemi verifikuar se teknologjia e prodhimit të sallamave, në kompaninë SHPK "Sole Kosova" metodologjia e përdorur gjatë teknologjisë së prodhimit të sallamave është brenda standarteve ligjore, dhe realizimi i saj mundësohet përmes pajiseve adekuate dhe kjo është përcjellur përmes fazave të këtij procesi si: përzgjedhja e lëndes së parë, bluarja e mishit, përzierja, mbushja në mbeshtjellës, tharja, paketimi dhe ruajtja.

Kualiteti i sallamave të prodhuara është verifikuar pëmes analizave laboratorike dhe rezulton se të dy mostrat e parizer pule 400 gr dhe parizer vici 400 gr janë të rregullta në aspektin organoleptik si dhe nën normat e lejuara në aspektin kimik, bazuar në përqendrimet e yndyrës, hirit, nitriteve, kripës, proteinave dhe sasisë së ujit. Gjithashtu rezulton se sallamat e testuara janë të sigurta sepse pas analizës mikrobiologjike nuk rezultojnë të pranishme asnjë nga llojet e mikroorganizmave të testuar si: Salmonella, Staphylococcus aureus, Escherichia coli dhe bakteret koloforme. 


\section{FALENDERIME}

Së pari dëshirojë të falenderoj Profesorin dhe të gjithë Profesorët të cilët me punën e tyre gjatë studimeve na dhanë dituri dhe në shumë raste ata u bënë edhe objekt motivi që me ndihmen e tyre të bëjnë të mundur për mua që të përfundoj me sukses studimet. Poashtu, dua të falenderoj edhe familjen time, përpjektet, inkurajimin, ndihmën dhe eduktata e të cilëve sot e kësaj dite japin shembull se si bëhen gjërat me guxim, përkushtim dhe me integritet. Sakrifica dhe puna e tyre e cila më shtyri të kaloj çdo barrier dhe që bejnë një shembull të përkushtimit që dua ta përcjellë tek të tjerët edhe unë një ditë. 


\section{Përmbajtja}

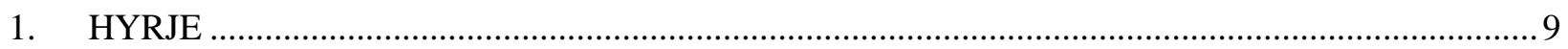

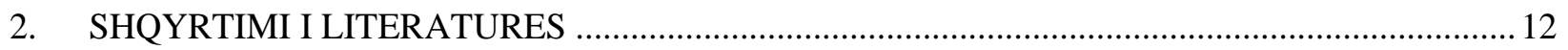

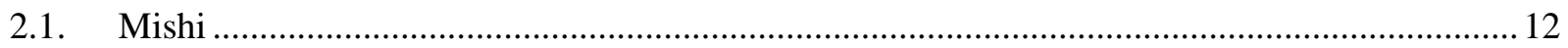

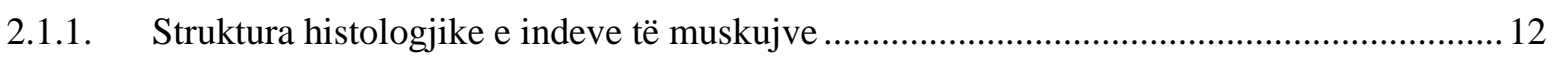

2.1.2. Vlerat ushqyese të mishit dhe produkteve të tij ............................................................ 18

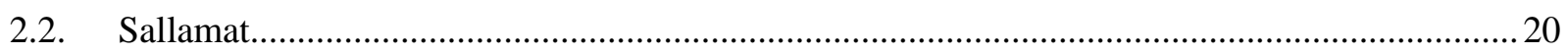

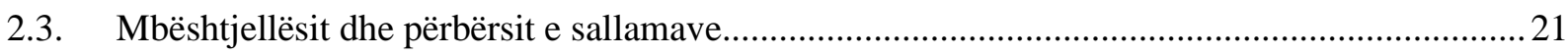

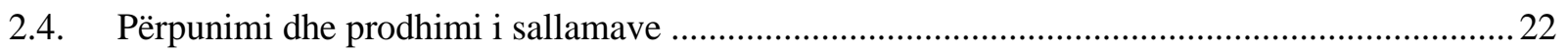

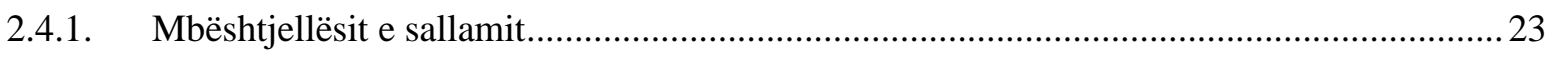

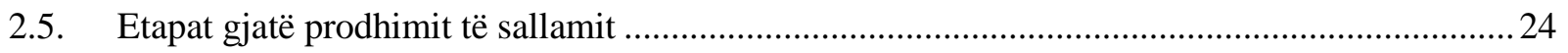

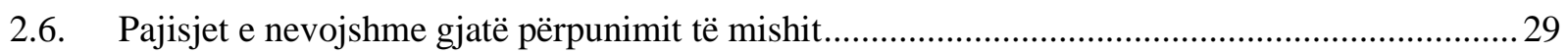

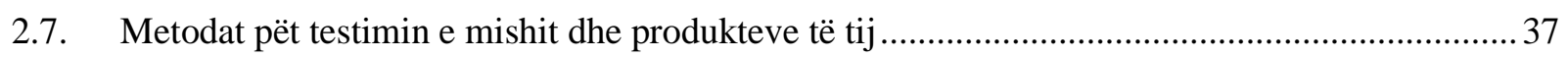

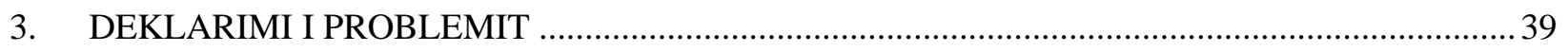

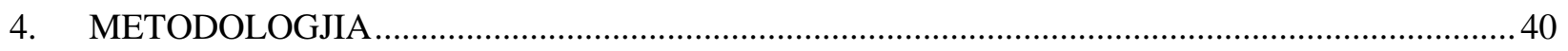

4.1. Metodologjia e prodhimit te sallamave në fabrikën SHPK "Sole Kosova" ...............................40

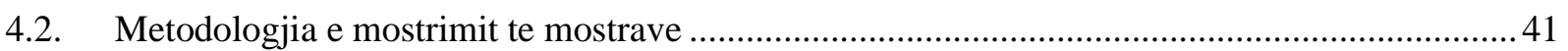

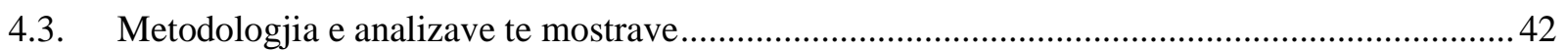

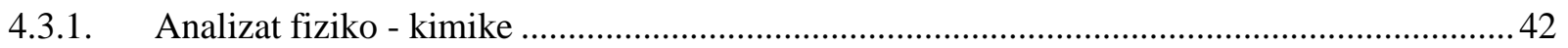

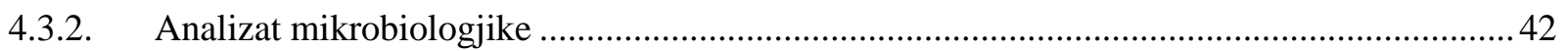

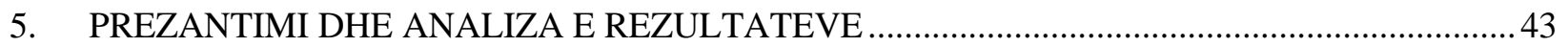

5.1. Prezantimi dhe analiza e razultateve rreth Metodologise se prodhimit te sallamave në fabrikën

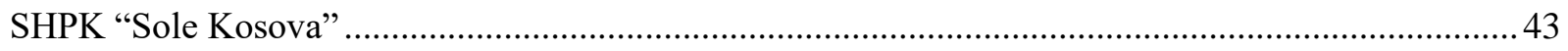

5.2. Prezantimi dhe analiza e razultateve rreth analizave fiziko- kimike dhe mikrobiologjike te

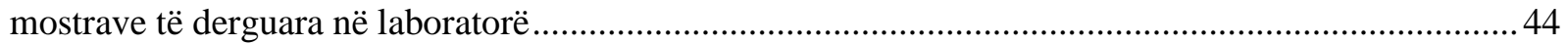

5.2.1. Rezultatet e analizave për produktin parizier pule 400GR …............................................ 44

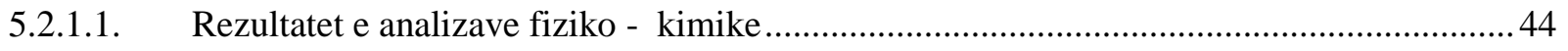

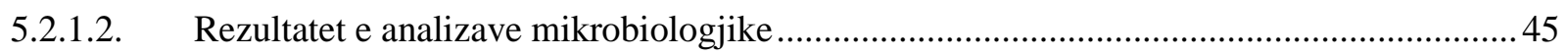

5.2.2. Rezultatet e analizave për produktin parizier viçi 400GR ............................................... 46

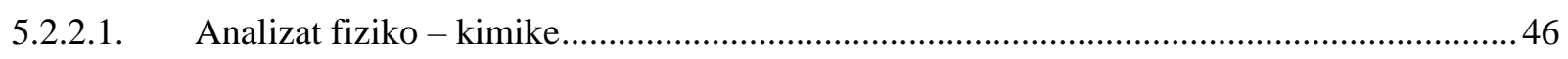

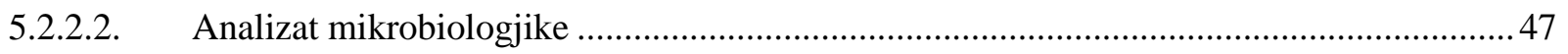

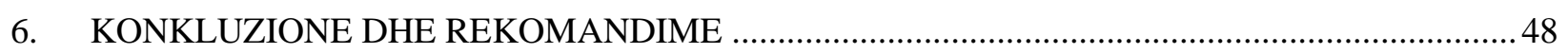

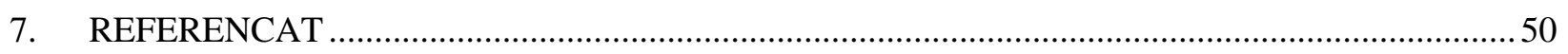

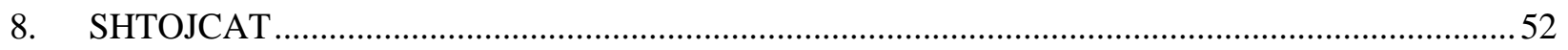




\section{Lista e Figurave:}

Figura 1. Struktura e muskulit skeletor si dhe e gjithë struktura e plotë e fibrës muskulore (qelizës muskulore).

Figura 2. Mish i freskët i prerë me ngjyrë të kuqe intensive.

Figura 3. Testi i kompresimit të mishit.

Figura 4. Tharja e mishit në dhomën e ftohjes.

Figura 5. Mish nga specie të ndryshme blegtoriale.

Figura 6. Sallamat e llojeve të ndyshme.

Figura 7. Sallamat e pjekura (cooked).

Figura 8. Sallama e tymosur.

Figura 9. Sallama e freskët.

Figura 10. Sallama e freskët e tymosur.

Figura 11. Salami.

Figura 12. Salsicet.

Figura 13. Makina grirëse e mishit moderne.

Figura 14. Prerësi në formë ene.

Figura 15. Makina për mbushje.

Figura 16. Makina për prerje dhe makina për mbushje e kombinuar.

Figura 17. Dhoma për tymosjen e mishit me gjenerator të ndarë për prodhimit e tymit.

Figura 18. Gjeneratori për prodhimin e tymit me fërkim.

Figura 19. Gjeneratori i kombinuar.

Figura 20. Makineria për injektimin e shëllirës në mish.

Figura 21. Masazhuesit e mishit.

Figura 22. Makinera për paketimin e mishit me vakum.

Figura 23. Makina emulsifikuese (mulliri koloid).

Figura 24. Makineria e dëborës.

Figura 25. Makinerit për prerjen e mishit të ngrirë: prerësi me thika vertikale dhe prerësi me thika rrotulluese.

Figura 26. Mbështjellësi i sallamit me cipa natyrale.

Figura 27. Mbushja e sallamit me cipa artificiale.

Figura 28. Lloj makine për grirjen e mishit që shërben si lënd eparë për prodhimin e sallamave.

Figura 29. Makineria për përgaditjen e pratit.

Figura 30. Mbushja e një lloji sallamit në mënyrë automatike.

Figura 31. Lidhja e sallamit në formën përfundimtare.

Figura 32. Mbajtëset metalike të sallamit gjatë pjekjes në furra.

Figura 33. pH matësi elektronik. 


\section{Lista e Tabelave :}

Tabela 1. Analiza fiziko - kimike te parizer pule

Tabela 2. Analiza mikrobiologjike te parizer pule

Tabela 3. Analiza fiziko - kimike te parizer vici

Tabela 4. Analiza mikrobiologjike te parizer vici 


\section{Fjalori i termave :}

MSG - Glukamate Monosodium 


\section{HYRJE}

Për të përfituar energjinë e cila nevojitet për aktivitet e përdishme jetesore, njeriu është i detyruar që këtë energji ta marrë përmes ushqimeve. Të gjitha ushqimet që njeriu konsumon ofrojnë materije të ndryshme dhe përbërës kimik të cilët luajnë rol të madh në zhvillimin e drejtë të organizmit të njeriut. Në mesin e ushqimeve tejet të rëndësishme në të ushqyerit e njeriut, padyshim që hyn edhe konsumimi i mishit dhe produkteve të tij.

Mishi dhe produktet e tij paraqesin burim të materjeve të rëndësishme në jetën e njeriut, e veçanarisht burim të lartë të proteinave, të cilat në përbërjen e tyre kanë aminoacide esenciale, të cilat organizmi i njeriut nuk mund t'i sintetizoj por si të tilla duhet të merren përmes mishit. Kjo gjë e bën të veçantë mishin, e që vjen edhe nga të kuptuarit e shkencës së pa proteina, gjegjësisht aminoacidet esenciale, organizmi i njeriut nuk mund të funksionojë normalisht.

Kuptohet që nëse njeriu tek mishi kërkon edhe energji, atëherë padyshim që atë mund ta gjejë edhe tek yndyrat e mishit te të cilat njëkohësisht kanë vlerat e saja ushqyese dhe energjetike, për periudhat kur njeriu i është nënshtruar aktiviteteve të sforcuara fizike. Padyshim që mineralet dhe vitaminat janë prezente në mish dhe produktet e tij, gjë që e kompleton përbërjen nutricionale të mishit.

Duke e parë rëndësinë e mishit dhe produkteve të tij në nutricionin e njeriut, kjo ka bërë që fermerët e kafshëve në mbarë botën të mbarështojnë kafshë nga të cilat përmes therjes së tyre do bëjnë furnizimin me mish, dhe krahas kësaj ka filluar të merrë hov edhe zhvillimi i ndërmarrjeve të prodhimit dhe përpunimit të mishit pikërisht në këto zona rurale ku edhe janë të pranishme kafshët për therje dhe të cilat prodhimin e mishit e kanë si aktivitet të tyre biznesorë. Kjo ka bërë që gjatë 200 viteve të fundit, industria e mishit të shëndrrohet nga një industri me teknologji të ulët në një furnizues të teknologjisë së lartë të ushqimeve proteinike cilësore për konsumatorët në të gjithë botën.

Kur është fjala për mishin është e rëndësishme të theksohet se ky paraqet një terren ushqyes shumë të mirë për bakteret, të cilat kanë afinitet që pas kontaminimit të zhvillohen në mish duke shkaktuar humbje të vlerave ushqyese dhe njëkohësisht duke e bërë mishin dhe produktet e tij madje të rrezikshme, duke shkaktuar intoksikacione, madje në disa raste edhe sëmundje infektive me pasoja të rënda për konsumatorin. 
Për të zgjatur kohën e qëndrueshmërisë së mishit, njeriu ka zhilluar edhe metoda të ndryshme të konzervimit të mishit si dhe përgatitjen e produkteve të ndryshme të cilat përveç që janë metodë e konzerzimit të mishit, krahas kësaj i ofrojnë konsumatorëve një gamë të gjërë dhe të larmishme të produkteve të cilat kanë përbërje dhe shije nga më të ndryshmet.

Ndër prodhimet e shumta të mishit, patjetër që vend të madh zënë edhe prodhimi i sallamave, $\mathrm{i}$ cila ka pasur një histori të gjatë dhe shumëngjyrëshe dhe zhvillimet gjatë disa dekadave të fundit kanë çuar në proces të aprovimit të një larmie të gjerë të produkteve të reja të sallamave, duke përfshirë edhe lloje dhe forma të reja të saj. Kuptohet që këtij zhvillimit të prodhimtarisë së sallamave i ka kontribuar edhe zhvillimi domethënës në fushën e shkencës së mishit dhe biokimisë, e cila krijoi një lidhje të ngusht mes artit tradicional të përgaditjes së sallamit dhe përpunimit modern.

Industitë për përpunimin e sallamave, jo vetëm në mbarë botën por edhe në Kosovë, i nënshtrohen standardeve ndërkombëtare të ushqimit, siç është Codes Alimentarius si dhe rregulloreve ligjore vendore, siç janë Udhezimet Adminstrative të Kosovës, të cilat kontribojnë në sigurinë, cilësinë dhe ndershërinë e tregtisë se ushqimit, ashtu që konsumatorët të besojnë në sigurinë dhe cilësinë e produkteve ushqimore të cilat ata i blejnë si dhe importuesit mund të besojnë se ushqimi që ata shesin do të jetë në përputhje me specifikimet e tyre.

Për të arritur standardet e tilla për përmbushjen e obligimeve ligjore të lartpërmendura, industritë për prodhimin e sallamave patjetër që kanë qenë të detyruara që të fusin në procesin e prodhimit lloje të reja të makinave, aplikimin e aditivëve të rinj kimikë, llojeve të reja të mbeshtjellesve, materialeve të paketimit si dhe ka pasur ndryshime edhe në konceptet e procedurave themelore të përdorura në prodhimin e sallames. Krahas kësaj, bazuar në standardet ligjore, produktet e prodhuara nga këto kompani, janë të detyruara që të aplikojnë metodat e vetkontrollit të prodhimeve të tij, si dhe njëkohësisht këto prodhime i nënshtrohen edhe kontrollave dhe analiza nga institucionet vendore më qëllim të verifikimit të kualitetit në përbërje si dhe në aspektin mikrobiologjik, e gjithë kjo që të mbajë në nivel të lartë prodhimtarinë e sallamave në mënyrë që ato të jenë të kualitetit të lartë dhe të parrezikshme për jetën e konsumatorit.

Pikërisht për të hulumtuar procedurat e teknologjisë të cilat perdoren në prodhimin e sallamave në Kosovë si dhe verifikimi i aplikimit të standardeve ligjore të cilat e rregullojnë këtë çeshtje gjatë 
prodhimit të sallamave, ne kemi ndërmarrë këtë studim të cilin e kemi realizuar në kompaninë për prodhimin dhe përpunimin e mishit SHPK "Sole Kosova”, me seli në Fushë Kosovë.

Për të verifikuar kualitetin e sallamave të prodhuara ne i kemi hulumtuar përmes analizave laboratorike të natyrës së treguesve të cilësisë (vlerave ushqyese), mikrobiologike dhe fizikekimike, teste këto që realizohen edhe në kuadër të kompanise "Sole Kosova". Megjithatë, për të analizuar sallamat e prodhuara në këtë kompani, ne kemi dërguar në qendrën e laboratoreve testues të Institutit Kombërtar të Shëndetësisë Publike të Kosovës (IKSHPK) gjatë muajit Shtator të vitit 2019, dy mostra të marra rastësisht gjatë mostrimit nga prodhimtaria ditore pas përfundimit të prodhimit, e që janë mostra të Parizer pule 400 gr. dhe parizer viçi 400 gr. Analizat ndaj këtyre sallamave kanë të bëjnë me analizat fiziko-kimike dhe analizat mikrobiologjike, që në fakt janë tregues të kualitetit të këtyre prodhimeve dhe këto rezultate do t'i pasqyrojmë më poshtë në këtë punimin tonë modest. 


\section{SHQYRTIMI I LITERATURES}

\subsection{Mishi}

Në përgjithësi, mishi përbëhet nga uji, yndyra, minerale dhe një pjesë e vogël e karbohidrateve. Komponenti më i rëndësishëm nga këndvështrimi ushqyes dhe përpunes është proteina. Përmbajtja e proteinave dhe vlerave të proteinave përcaktojnë cilësinë e materialit të papërpunuar të mishit dhe përshtatshmërinë e tij për përpunim të mëtejshëm. Përmbajtja e proteinave është gjithashtu kriter për cilësinë dhe vlerën e produkteve të përpunuara të mishit. Uji është një vlerë e ndryshueshme e këtye përbërësve dhe lidhet në mënyrë të dyanshme me vlerat e yndyrës. Përmbjtja e yndyrës është gjithashtu e lartë në produktet e mishit të përpunuar, ku përdoren sasi të larta të indit yndyror. ( Handbook of Food Chemistry, 2014)

Vlerat e ushqimeve shtazore është e lidhur ngusht me përmbajtjen e tyre të proteinave. Proteina është e përbërë nga rreth 20 aminoacide. Përafërsisht $65 \%$ e proteinave në trupin e kafshëve janë proteina të muskujve të skeletit, rreth $30 \%$ janë proteina të indit lidhës (kolagjen, elastin) dhe pjesa e mbetur 5\% përbëhet nga proteinat e gjakut dhe keratinës. ( Gunter and Peter Hautzinges, 2007)

\subsubsection{Struktura histologjike e indeve të muskujve}

Muskujt janë të rrethuar nga një membranë e indit lidhës, skajet e së cilës bashkohen në një tendin të ngjitur në skelet. Çdo muskul përfshinë disa tufa fibrash të muskujve të cilat janë të dukshme edhe për syrin tonë, të cilat përmbajnë një numër të ndyshëm (30-80) të fibrave të muskujve ose qelizave të muskujve deri në disa centimetra të gjata me një diameter $0.1 \mathrm{~mm}$. Madhësia dhe diametri i fibrave të muskujve varet nga mosha, lloji dhe raca e kafshëve. Mes tufave të fibrave muskulore gjenden enët e gjakut si dhe depozitat e indit lidhor dhe atij yndyror. Çdo fibër muskulore (qelizë muskulore) është e rrethuar me një membranë qelizore që njihet si sarkolema. Brenda qelizës janë sarkoplazma dhe një numër i madh i filamenteve të quajtura edhe si miofibrile. ( Gunter and Peter Hautzinges, 2007).

Kjo mund të shihet edhe në figurën e më poshtme : 


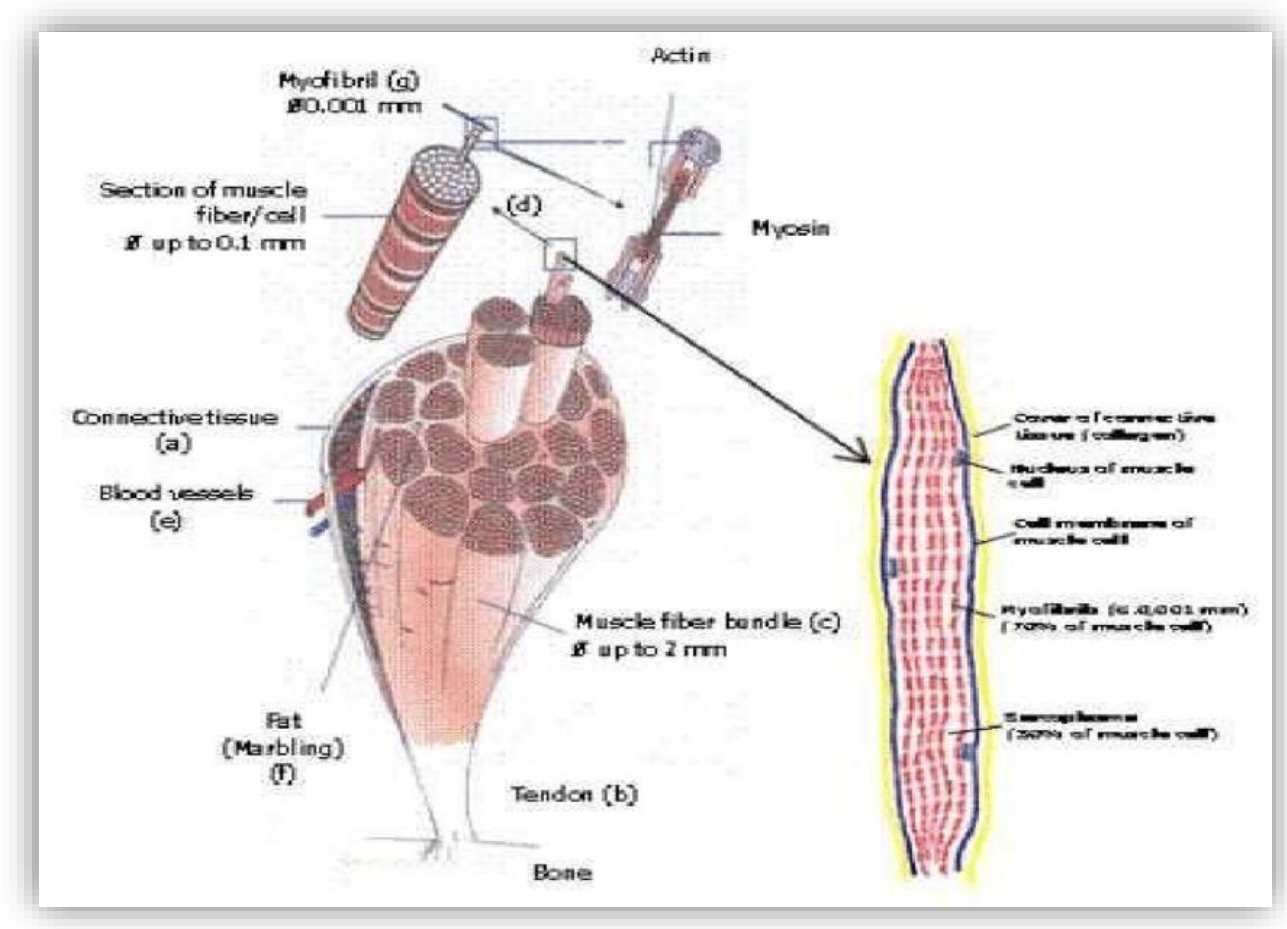

Figura 1. Struktura e muskulit skeletor si dhe e gjithë struktura e plotë e fibrës muskulore (qelizës muskulore).

Ndryshimet e $\boldsymbol{p H}$ - menjëherë pas vdekjes muskuli përmban një sasi të vogël të karbohidrateve specifike të njohur si glukogjen (rreth 1\%), ku shumica e të cilës është e zbërthyer në acid laktik në mishin e muskujve në orët e para (deri në 12 orë) pas therrjes. Ky proces biokimik shërben si një funksion i rëndësishëm në përcaktimin e aciditetit në mish.

I ashtuquajturi cikli glikolitik fillon menjëherë pas therjes në indin e muskujve, në të cilin glikogjeni furnizuesi kryesor i energjisë në muskulë, prishet në acid laktik. Ndërtimi i acidit laktik në muskuj prodhon një ulje të aciditetit të tij, siç matet me pH. pH e një muskuli normal është 7.0 gjatë therjes, por kjo vlerë ulet në mish. Në një kafshë normale, pH përfundimtare (i dhënë si $\mathrm{pH} 24=24$ orë pas therjes) bie në rreth $\mathrm{pH}$ 5.8-5.4. Shkalla e zvogëlimit të $\mathrm{pH}$ e muskujve pas therjes ka një efekt të rëndësishëm në cilësinë e mishit që rezulton.

Shija tipike dhe aroma e mishit arrihet vetëm pas rënies së mjaftueshme të pH-së 5.8 në 5.4. nga pikpamja e përpunimit, mishi me pH 5.6 - 6.0 është mëi mirë për produktet ku kërkohet lidhje e mirë e ujit (salcicet e tymosura dhe proshuta e gatuar), pasi që mishi me pH më të lartë ka një kapacitet më të lartë të lidhjes me ujin. Në produktet që humbasin ujin gjatë fabrikimit dhe pjekjes 
(p.sh. proshuta e papjekur dhe salsicet e thara), mishi me pH më të ulët (5.6-5.2) preferohet pasi ka një kapacitet më të ulët të lidhjes me ujin.

pH është gjithashtu e rëndësishme për ruajtjen e mishit. Sa më e ulët pH, kushtet për rritjen e bakterieve janë më të ulëta. Mishi i kafshëve, i cili ka zbrazur rezervat e tyre të glikogjenit para therjes (pra, gjatë transportit stresues/ hapsirave për mbajtjen e kafshëve) nuk do të ketë një rënie të mjaftueshme të pH-së dhe nuk do të jetë shumë e prirur për asgjësimin e baktereve. (Huff Lonergan E, Zhang W, Lonergan SM 2010)

Ngjyra e mishit - pigmenti i kuq i cili siguron ngjyrën karakteristike të mishit quhet mioglobinë. Ngjashëm me hemoglobinën pikmentin e gjakut transporton oksigjenin në inde tek kafsha e gjallë. Konkretisht, mioglobina është oksigjeni rezervë për qelizat e muskujve ose fibrat muskulore. Oksigjeni është i nevojshëm për procesin biokimik që shkakton kontraktimin e muskujve te kafshët e gjalla. Sa më i madh të jetë përqendrimi i mioglobinës, aq më e fortë është ngjyra e muskujve. Ky ndryshim në përqëndrimin e mioglobinës është arsyeja pse shpesh ekzistion një grup muskulor më i lehtë ose më i errët se një tjetër në të njejtin mish të therrur (karkase).

Përqëndrimi i mioglobines në muskuj ndryshon gjithashtu edhe mes specieve. Mishi i lopës (beef) ka dukshëm më shumë mioglobinë sesa derri, viçi ose qengji, duke i dhënë kështu mishit të lopës ngyrë më intenzive. Pjekuria e kafshës ndikon gjithashtu në intensitetin e pigmentimit, pra kafshët më të moshuara kanë pigmentim më të errët. Nivelet e ndryshme të mioglobinës përcaktojnë edhe aftësin e konservimit të mishit për shkak se kur ka më shumë miglobine ka më shumë ngjyrë në dispozicion. ( Surendranath P. Suman1* and Poulson Joseph 2013).

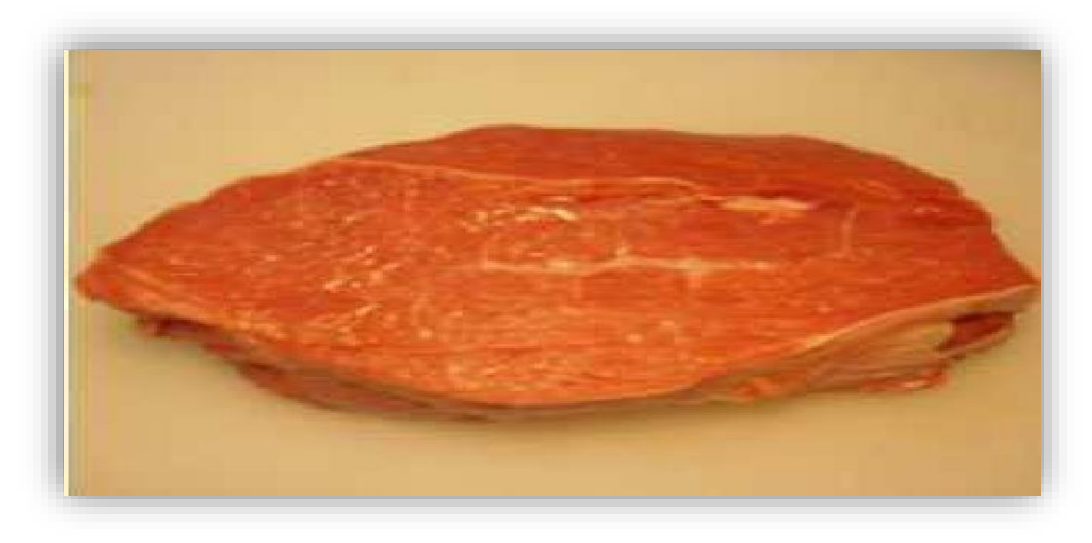

Figura 2. Mish i freskët i prerë me ngjyrë të kuqe intensive 
Kapaciteti i mbajtjes së ujit të mishit - është një nga faktorët më të rëndësishëm të cilësisë së mishit si nga pikpamja e konsumatorit ashtu edhe nga prodhuesi. Proteinat e muskujve janë të afta të mbajnë shumë molekula uji në sipërfaqen e tyre. Kur indi muskulor zhvillon apo rrit aciditetin (zvoglon pH-në) ai zvoglon edhe kapacitetin e ujit mbajtës.

Uji i lidhur me proteinën e muskujve ndikon në cilësinë e ngrënies dhe përpunimit të mishit. Për të marrë rendimente të mira gjatë përpunimit të mëtejshëm, përfshirë gatimin, kapacitetit mbajtës i ujit duhet të jetë në një nivel të lartë (përveç produkteve të fermentuara, të papërpunuara apo produkteve të thata të cilat duhet të humbasin ujin gjatë përpunimit).

Kapaciteti mbajtës i ujit ndryshon shumë mes muskujve të trupit dhe mes specieve shtazore. Është zbuluar se mishi tulë ka aftësinë më të madhe për të mbajtur ujin, pastaj vjen mishi i derrit dhe në fund vjen mishi i shpendëve që kanë më së paku ujë.

Në figurën e më poshtme, shohim ndryshimet ndërmjet mishit me kapacitet të ulët të mbajtjes së ujit i cili gjendet në anën e majt ndërsa në anën e djatht ku shihet mishi me ngjyrë më të errët mund të dallojmë se ka kapacitet më të lart të mbajtjes së ujit. (Gou P, Arnau J, Garcia-Gil N, Fulladosa E, Serra X 2012)

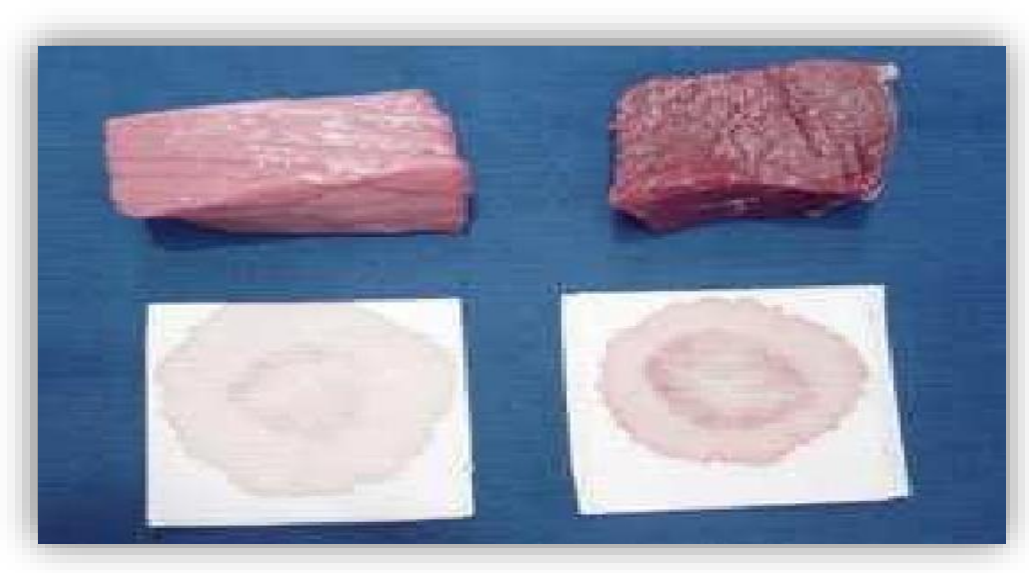

Figura 3. Testi i kompresimit të mishit.

Ndjeshmëria apo butësia dhe aroma - butësia e mishit luan një rol të rëndësishëm, ku copa të tëra mishi gatuhen, skuqen apo përgaditen në grill. Në këto raste, disa lloje te mishit e veçanarisht mishi i lopës (beef), duhet të kalojë një periudhë të caktuar të pjekjes apo një periudhë tharje para se të përdoret për gatim apo konsumim, ashtu që të arrijë butësin e duhur. 
Në fabrikimin e shumë produkteve të përpunuara të mishit, ashpërsia apo butësia e mishit të përdorur nuk ka shumë rendësi. Shumë produkte të mishit janë të përbërë nga mish i grimcuar, një proces ku edhe mishi i forcuar më parë bëhet i këndshëm. Përpunimi i mëtejshëm i mishit i pjesëve më të mëdha të mishit (psh. Proshuta e papërpunar dhe e pa pjekur) gjithashtu rezulton me një cilësi të mirë pasi që këto produkte konzervohen dhe fermentohen, gjë që i bën më të butë dhe lehtë të përtypshëm.

Në figurën e më poshtme mund të shohim procesin e fermentimit të mishit në dhomën e ftohjes.

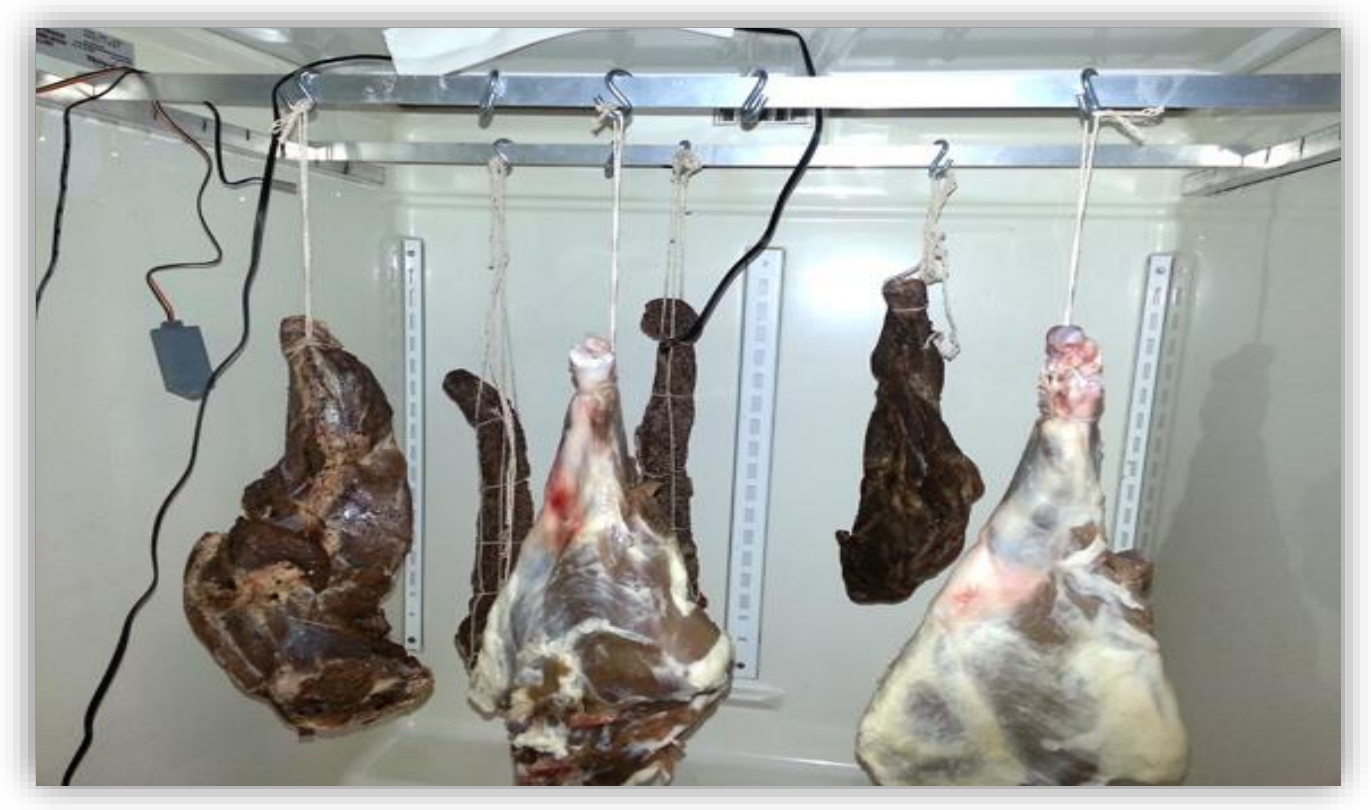

Figura 4. Tharja e mishit në dhomën e ftohjes.

Shija e mishit është e ndryshme për lloje të ndryshme të kafshëve. Sidoqoftë, ndonjëherë mund të jetë më e vështirë të dallohen disa lloje të mishit kur përgaditen në ushqim, si psh., në disa raste mishi i derrit dhe mishi i viçit mund të ketë shije të ngjashme dhe të ketë të njejtat veti përtypëse. Mishi i delës dhe ndonjëherë edhe qengjit ka një shije dhe erë karakteristike, e cila buron nga yndyra. Edhe sasit e vogla të yndyrës si inter dhe intramuskulare mund të shkaktoj këtë erë tipike në mish, veçanarisht tek kafshët më të vjetra. (Gunter Heinz and Peter Hautzinger, 2007 ).

Ushqyerja e kafshës ndonjëherë ndikon në shijen e mishit (mishi i peshkut). Për më tepër, edhe gjinia e kafshës mund të jap një shije dhe erë të veçantë të mishit. Shembulli më i mirë është era e theksuar në formë urine kur gatuani mish derri të vjetër. Mirëpo, mishi i cili është i përshtatshëm për konsumim tek njerëzit por ka një erë dhe shije i cili mund të mos jetë i përshtatshëm për gatim, 
mund të përdoret akoma tek disa produkte të mishit të përpunuar. Sidoqoftë, preferohet të përzihet me mish normal për të minimizuar aromën e jashtme. Gjithashtu edhe përdorimi i erëzave mund të ndihmoj në këtë drejtim.

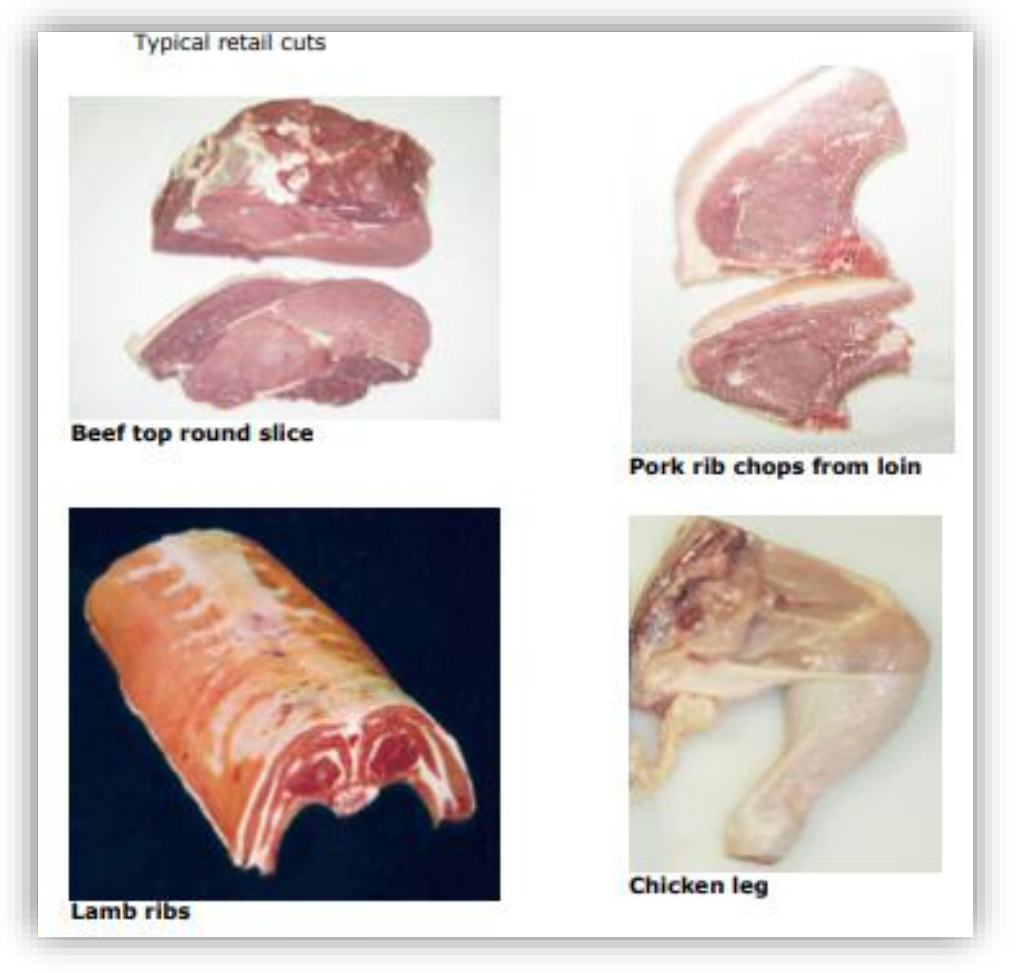

Figura 5. Mish nga specie të ndryshme blegtoriale.

Shija dhe era tipike e dëshirueshme e mishit është në mas të madhe rezultat $\mathrm{i}$ formimit të acidit laktik (e cila vjen nga prishja e glukogjenit në indin e muskujve) dhe komponimeve organike që janë aminoacidet si dhe di dhe tri-tripeptidet të ndara nga proteinat e mishit.

Në veçanti mishi i vjetëruar (“pjekur”) merrë shijen e tij karakteristike nga prishja e substancave të tilla. Shija e mishit mund të përmirësohet më tej duke shtuar glukamate monosodium (MSG) (0.5- $0.1 \%$ ), e cila mund të forcoj shijen e mishit tëk disa produkte të caktuara. MSG është një përbërës i cili shumë shpesh përdoret tek gatimet e mishit dhe produkteve të tij e sidomos tek vendet aziatike. (Arnau Arboix J, 2004). 


\subsubsection{Vlerat ushqyese të mishit dhe produkteve të tij}

Proteinat - vlera ushqyese e mishit është në thelb e lidhur me përmbajtjen e proteinave me cilësi të lartë. Proteinat me cilësi të lartë karakterizohen nga përmbajtja e aminoacideve thelbësore të cilat nuk mund të sintetizohen nga trupi ynë, por duhet t'i marrim përmes ushqimit tonë. Në këtë aspekt, ushqimi i përgaditur nga mishi ka një avantazh ndaj atyre me origjinë bimore.

Ekzistojnë proteina bimore të cilat kanë vlerë biologjike mjaft të lartë si psh, proteina e sojës, vlera biologjike e së cilës është rreth $65 \%$ e asaj të mishit. Përqëndrimet e proteinës së sojës janë gjithashtu përbërës shumë i dobishëm në shumë produkte të përpunuara të mishit, ku jo vetëm që rrisin vlerën ushqyese, por kryesisht edhe rrisin edhe lidhjet e ujit dhe emulsifikimin e yndyrës. Proteinat kontraktile ose proteinat miofibrile janë vlera mjaft të rëndësishme sasiore (rreth 65\%) dhe janë gjithashtu të rëndësishme si vlera cilësore pasi ato kanë vlera të larta biologjike.

Indet lidhëse përmbajnë kryesisht kolagjen, i cili ka një vlerë të ulët biologjike. Elastina është plotësisht e padepërtueshme. Kolagjeni është i tretëshëm, por nuk është aminoacid tripofanit thelbësor. Proteinat e gjakut kanë një përmbajtje të lartë të tripofanit, por megjithatë janë me vlerë më ulët biologjike se mishi përshkak të mungesës së aminoacidit izolucin. (Huff Lonergan E, Zhang W, Lonergan SM 2010)

Yndyrat - yndyrat e kafshëve janë kryesisht trigliceride. Kontributi kryesor i yndyrës në diet është energjia dhe kaloritë. Përmbajtja e yndyrës në trupat e kafshëve ndryshon nga 8 deri rreth $20 \%$ (kjo e fundit vetëm tek mishi i derrit). Përmbajtja e acideve yndyrore është shume e ndryshme në vende të ndryshme. Yndyrat e jashtme (“dhjami i trupit”) është shumë më i butë sesa yndyrat e brendshme që rrethojnë organet për shkak të përmbajtjes së lartë të yndyrave të pangopura në pjesët e jashtme.

Acidet yndyrore të pangopura (acidi linoleik, linolenik dhe archidonik) janë vlera fiziologjike dhe ushqyese të rëndësishme pasi ato janë përbërës të domosdoshëm të mureve qelizore, mitokondriave dhe vendeve të tjera intensivisht metabolike të organizmit të gjallë. Trupi i njeriut nuk mund të prodhojë me lehtësi asnjë prej acideve yndyrore të mësipërme, kështu që ato duhet të vihen në dispozicion në diet. Mishi dhe produktet e mishit janë burime relativisht të mira, por në disa produkte bimore siç janë drithërat dhe farat, acidi linoleik zakonisht është i pranishëm në rreth 20 herë më shumë sesa përqendrimi që gjendet në mish. 
Vitet e fundit është sugjeruar që një raport i lartë i acideve yndyrore të pangopura/ ngopura në ushiqim është e dëshirueshme pasi që kjo ulë ndjeshmërinë e individit ndaj sëmundjeve kardiovaskulare në përgjithësi dhe sëmundjeve të zemrës. Ekzistojnë prova të cilat tregojnë se përdorimi i yndyrave të ngopura në ushqim (si ato të mishit) rrisin nivelin e kolesterolit në gjak. Për të shmangurë rreziqet e mundshme shëndetsore nga konsumimi i mishit, grupet e prekshme duhet të zvoglojnë marrjen e yndyrës së kafshëve. (Cobiac L, Droulez V, Leppard P et al. 2003)

Vitaminat - mishi dhe produktet e mishit janë burim shumë i mirë i vitaminës B-complex. Mishi i derrit është burimi më i mirë ushqimor i tiaminës (vitaminës B1) më shumë se $1 \mathrm{mg} / 100 \mathrm{~g}$ në krahasim me mishin e viçit, i cili përmbanë vetëm rreth $1 / 10$ e kësaj sasie. Kërkesat ditore për këtë vitaminë mjaft të rrallë është 1-1,5 mg. Në ushqimet bimore vitamina B12 nuk gjendet fare, kështu që mishi është një burim i mirë i kësaj vitamine për fëmijet, pasi që në organizmin e tyre depozita e vitaminës B12 duhet të jetë e qëndrueshme. Në anën tjetër, mishi është i varfër në yndyrat e tretshme në vitaminat $\mathrm{A}, \mathrm{D}, \mathrm{E}, \mathrm{K}$ dhe $\mathrm{C}$.

Megjithatë, organet e brendshme veçanarisht mëlçia dhe veshkat, në përgjithësi përmbajnë një përqindje të konsiderueshme të vitaminës A, C, D, E dhe K. Shumica e vitaminave në mish janë relativisht të qëndrueshme gjatë gatimit ose përpunimit, megjithëse sasi të konsiderueshme mund të shpërndahen gjatë tharjes apo zirjes. Tiamina (Vitamina B1) dhe në një masë më të vogël vitamina B6 janë të ndjeshme ndaj nxehtësisë. Këto vitamina shkatërrohen pjesërisht gjatë gatimit dhe konzervimit .( Purchas R, Zou M, Pearce P et al. 2007)

Mineralet - përmbajtja e mineraleve tek mishi, përfshirë kalciumin, fosforin, natriumin, kaliumin, klorin dhe magnezin ku me nivelin e secilit prej këtyre mineraleve mbi 0,1\%, dhe elementeve të cilat lënë gjurmë si hekuri, zinku dhe shumë të tjerë. Gjaku, melçia, veshkat organet e tjera me ngjyrë të kuqe dhe në një masë edhe mishi i bluar, dhe në veçanti janë burime të mira të hekurit. Marrja e hekurit është e rëndësishme për të luftuar aneminë, e cila veçanarisht në vendetet në zhvillim është më e përhapur në mesin e fëmijëve dhe grave shtatëzana. Hekuri në mish ka një bio-disponueshmëri më të lartë, resorbim më të mirë dhe metabolizë sesa hekuri në produktet bimore. (Cabrera,M.C., \& Saadoun, A. 2014) 


\subsection{Sallamat}

Sallama është forma më e vjetër e produkteve të përpunuara të mishit të njohura deri tani. Gjithashtu kosiderohet si një ndër produktet më të shijshme, kalorike, të këndshme dhe të përshtatshme nga produktet e mishit. Sallama është një produkt cilindrik prej mishi, i cili zakonisht përbëhet nga mish i grirë shpesh nga derri, lopa dhe viçi, shpendë të ndryshme dhe së bashku me erëza të ndryshme, krip dhe aromatizues të tjerë, trosha buke dhe një janë të mbështjellur me një lekurë. Zakonisht, mbështjellësi i sallamave është i formuar nga zorrët, mirëpo ndonjëherë është i formuar edhe nga materiale sintetike. Sallamat të cilat shiten të papërpunuara gatuhen në shumë mënyra, si skuqje në tigan, zirje apo nëpër skara. Ndërsa disa sallama janë gatuar gjatë përpunimit, mbështjellësi i tyre mundet vetëm të ju hiqet.

Në figurën e mëposhtëme mund të shohim sallamat e llojeve të ndryshme si: sallama e bardhë, sallama e tymosur si dhe lloje tjera të sallamave polake.

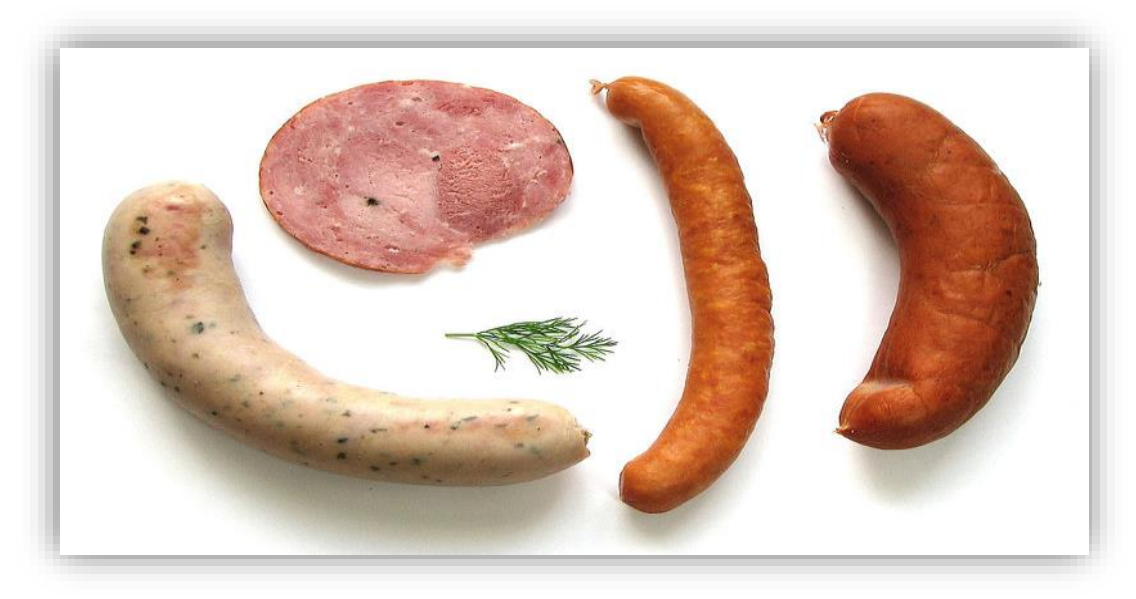

Figura 6. Sallamat e llojeve të ndyshme.

Sallamat janë një teknik tradicionale e ruajtjes së ushqimit. Sallamat mund të ruhen me anë të konzervimit, tharjes (shpesh në bashkpunim me fermentimin apo kultivimin, i cili mund të kontribojë në ruajtjen e sallamit), tymosjes apo edhe ngrirjes. Sallamat e konzervuara dhe tymosura mund të ruhen edhe pa ftohje. Shumica e sallamave të freskëta duhet të ruhen në frigorifer ose të ngrihen deri sa nevojiten për gatim.

Sallamat vijnë në një gamë të madhe të llojeve kombëtare dhe rajonale, të cilat ndryshojnë nga përbërsit e tyre aromatizues dhe erëzave (si hudhra, specat, verërat etj), mishi i përdorur në to dhe mënyra e përgadites. 
Sallamat janë rezultat i një therje efikase. Tradicionalisht, prodhuesit e sallamit kripojnë inde dhe organe të ndryshme si mbetjet e mishit, mishin e organeve të ndryshme, gjakun dhe yndyrën e tyre për të ndihmuar në ruajtjen e sallamit. Pastaj, bëhet mbushja e zorrëve tubulare të bëra nga zorrët e pastërta të kafshëve, duke marrë formën e tyre karakteristike cilindrike. Prandaj, salsicet dhe sallamat mund të themi se janë ndër ushqimet më të vjetra të përgaditura, të gatuara apo të ngrëna menjëherë apo të thara në shkallë të ndryshme. "(Sebranek JG ,2003)

\subsection{Mbështjellësit dhe përbërsit e sallamave}

Mbështjellësit - Tadicionalisht, mbështjellësit e sallamëve janë bërë nga zorrët e pasterizuara të kafshëve ose nga stomakët e kafshëve në rastet e sallamëve të gjakosur. Sidoqoftë sot, mbështjellësit natyral janë zëvendësuar me kolagjen, celulozë apo mbështjellës plastik, veçanarisht tek rastet e sallamave të përpunuara në mënyrë industiale.

Disa forma të sallamit, sallmët e prerë në feta përgaditen pa mbështjellës. Për më tepër, mishi i cili përdoret brenda ditës dhe mishi i sallamit tani janë të disponueshme edhe pa mbështjellës, të cilët gjenden nëpër kavanozë dhe kanaçe.

Përbërësit - Një sallam përbëhet nga mishi i prerë në copa apo i grirë, i përzierë me përbërës të tjerë dhe i mbushur në zorrë. Përbërësit mund të përmbajnë përbërës më të thjesht si: trosha buke, erëza të ndryshme dhe aromatizues, ndërsa ndonjëherë mund të përmbajnë edhe mollë apo presh. Mishi mund të jetë nga kafshë të ndryshme si nga derri, lopa ose viçi apo edhe shpezët, kjo varet nga përzgjedhja e prodhuesve.

Përmbajtja e mishit siç etiketohet mund të etiketohet si 100\%, e cila ndodh kur pesha e mishit kalon peshën totale të sallamit pasi është bërë, ndonjëherë duke përfshirë një proces tharje i cili zvogëlon përmbajtjen e ujit. Në disa juridicione ushqimet e përshkruara si sallame duhet të plotësojnë rregulloret e përmbajtjes së tyre. Psh, në Shtetet e Bashkuara departamenti i bujqësisë specifikon përbajtjen e yndyrës së llojeve të ndryshme të sallamit, të cilat nuk duhet të kalojnë vlerat 30\%, 35\%,50\% nga pesha. Disa lloje mund të përmbajnë edhe lidhës apo zgjatues. (FAO Corporate Document Repository, 2010. )

Shumë stile tradicionale të sallamit në Azi dhe në Europën kontinentale nuk përdorin mbushës me bazë buke dhe përmbajnë vetëm mish, yndyra dhe aromatizues. Në Mbretërinë e Bashkuar dhe 
vendet e tjera me tradita angleze të kuzhinës, sallamët përmbajnë një pjesë të konsiderueshme të bukës dhe mbushësve me bazë niseshteje, të cilat përmbajnë $30 \%$ të përbërësve. Mbushësit $\mathrm{i}$ ndihmojnë sallamit të mbajnë formën e tyre ashtu si janë përgaditur. Derisa mishi kontraktohet në nxehtësi, mbushësi zgjerohet dhe thith lagështinë dhe yndyrën nga mishi.

Kur industrit e përpunimit të ushqimit prodhojnë sallama me çmime të ulëta, pothuajse çdo pjesë e kafshës përfundon në sallam, që dallojnë nga të lirë, të yndyrshëm të mbushur nga mish i shpërthyer nga mish i rikuperuar mekanikisht dhe thërmija buke. Në anën tjetër, cilësia e mirë përmbanë vetëm mish të zgjedhur dhe erëza.

Sallamet janë produkte të tipit emulsion. Ato përbëhen nga globula të ngurta të yndyrës, të shpërndara në tretësirë proteinike. Proteinat funksionojnë duke mbështjellë yndyrën dhe duke i stabilizuar ato në ujë. (FAO Corporate Document Repository, 2010. )

\subsection{Përpunimi dhe prodhimi i sallamave}

Prodhimi i sallameve fillon me pranimin dhe selektimin e mishit. Pas pranimit të mishit bëhet maturimi i tij, proces ky që shërben më pas për grirjen e mishit. Sallamet prodhohen nga mishi i të gjitha llojeve të kafshëve. Mishi i derri ka qenë më i përdoruri në shumë vende, mirëpo kohët e fundit mishi i viçit është më i zakonshëm në përdorim. Mishi tulë është përbërësi më i rëndësishëm i përdorur për sallam, sepse ka një kapacitet të lartë të ujit mbajtës që ruan komponentët yndyrorë në përzierje dhe përcakton aftësinë ngjitëse në bashkimin e komponentëve. Sa më e lartë të jetë sasia e mishit tulë, aq më e lartë është cilësia e produktit përfundimtar dhe aq më të vogla janë problemet gjatë procesit të prodhimit.

Në përgjithësi preferohet mish i freskët, por edhe mishi i ngrirë i cilësisë së lartë ka cilësi funksionale për të dhënë produkte të kënaqshme. Mishi i ngrirë është mirë të përdoret pa u shkrirë. Uji përbën 30-40\% të recepturës totale dhe është shumë i rëndësishëm në rritjen e aftësisë lidhëse të mishit dhe siguron kushte fluide gjatë procesit të copëtimit të yndyrës. Përqindja e ujit rritet deri në 50\% me anë të copave të akullit me qëllim që të minimizohet sa më shumë rritja e temperaturës gjatë procesit të përpunimit dhe të ulet aktiviteti i mikroorganizmave gjatë procesit të përpunimit.

Uji që përdoret duhet të jetë ujë i pijshëm me përbërje kimike të kënaqshme. Miellrat kontribojnë në shijen dhe teksturën e sallami, por gjithashtu thith edhe pjesën e lagështirës së ngelur. Më pas 
shtohen përbërësit e tjerë si kripa, erëzat, produktet e sojës, pluhur qumështi, kazeinë etj, shtohen gjithashtu edhe konservantët si dioksidi i sulfurit, fosfatet etj. Pas përzierjes bëhet mbushja dhe lidhja si dhe në fund faza përfundimtare paketimi i sallamit të prodhuar. (Food and Agriculture Organization of the United Nations. 1985)

\subsubsection{Mbështjellësit e sallamit}

Cipat mbështjellëse përbëjnë $10 \%$ të peshës totale të sallamit dhe janë dy llojesh natyrale dhe artificiale. Qëllimi i mbështjellëseve është dhënia e formës dhe mbrojtja e brumit nga faktorët e jashtëm.

Mbështjellësit natyral të sallamit - Cipat natyrale përbëhen nga zorrët e gjedhit, të derrave ose të deleve. Mbas pastrimit zorrët paketohen në $\mathrm{NaCl}$ të ngurtë ku kanë një jetëgjatësi infinite virtualisht në temperaturën $5^{\circ} \mathrm{C}$. Çkriposja e tyre mund të bëhet me anë të njomjes ose mbështetjes me një rrotull përpara përdorimit.

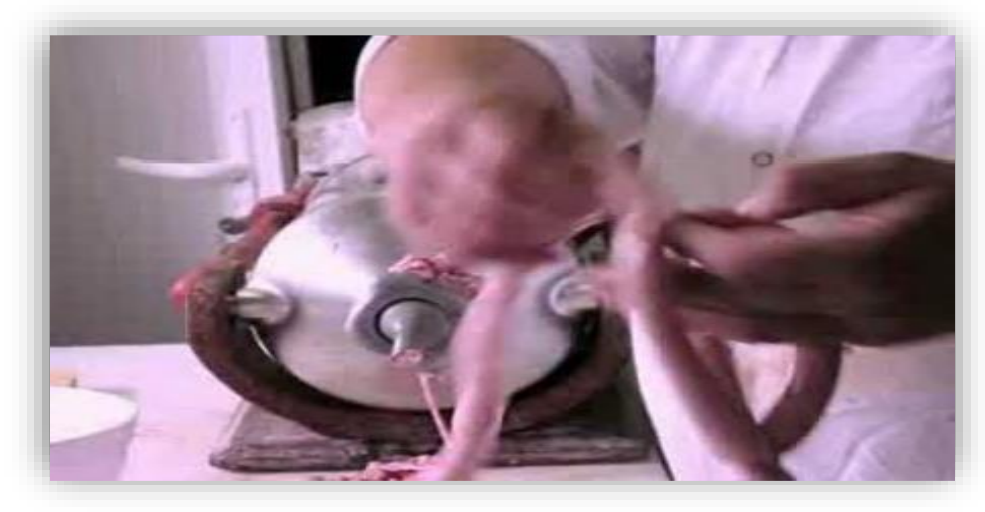

Figura 26. Mbështjellësi i sallamit me cipa natyrale.

Mbështjellësit artificial të sallamit - Përdorimi i cipave natyrale konsiderohet më origjinal dhe jep një sensacion të këndshëm në përtypje, por përdorimi i tyre është i kufizuar nga sasitë e vogla operacionale, ndërsa cipat artificiale sot përdoren më shumë për sigurin e tyre si dhe për lehtësinë që kanë për tu përdorur pa përgatitje paraprake. Ato janë më të forta dhe me diametër më të qëndrueshëm. Duke qenë se cipat artificial janë në përgjithësi të drejta dhe jo të përkulura sjellin shumë lehtësi në pajisjet paketuese automatike. 


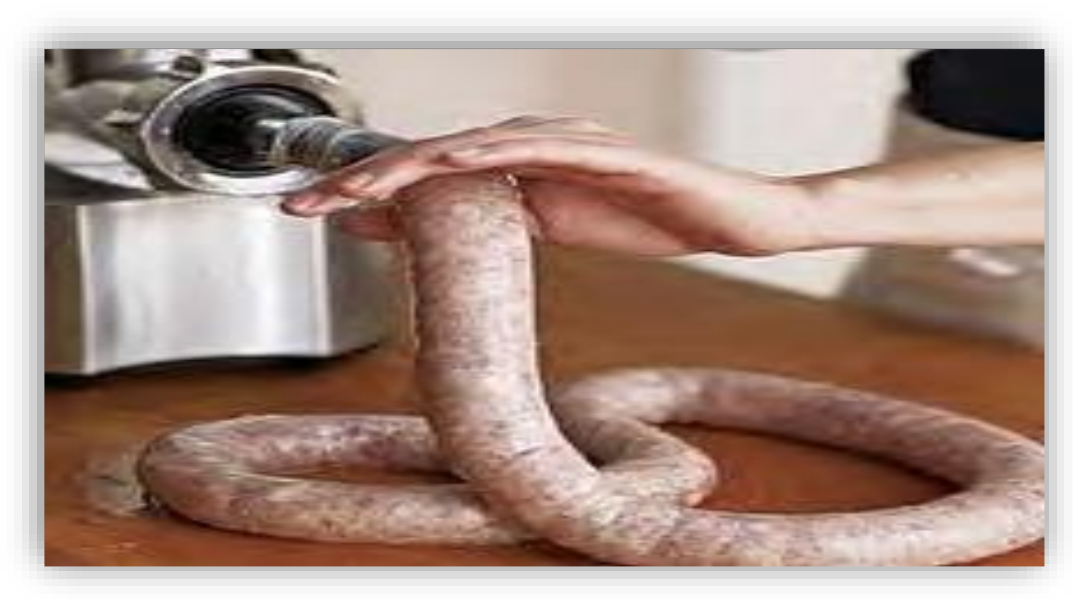

Figura 27. Mbushja e sallamit me cipa artificiale.

Materiali më i përdorshëm është kolagjeni, i cili përgatitet me tretjen e lëkurës me acid dhe duke ekstraktuar kolagjenin në një solucion të koncentruar të sulfatit të amoniumit. Nga kjo kolagjeni precipitohet si një tub në mënyrë të vazhdueshme. Këtij kolagjeni i shtohen komponime të ndryshme si celuloza dhe derivatet e saj, të cilat e bëjnë cipën e kolagjenit më të ngjashme me zorrët që përdoren si cipa natyrale. (UGA Extension Bulletin, 2014)

\subsection{Etapat gjatë prodhimit të sallamit}

Pranimi dhe seleksionimi $\boldsymbol{i}$ mishit - Pas pranimit të mishit ai vendoset në frigorifer, dhe mbahet aty në gjendje të ftohur në temperaturë $4-6{ }^{\circ} \mathrm{C}$, i varur në distancë trupi nga trupi $3-5 \mathrm{~cm}$. Këtu mishi mbahet për një kohë të shkurtër para përpunimit, në mënyrë që të mos pësoj ndryshime të padëshirueshme, që ndikojnë në produktin e prodhuar. Bëhet qërimi dhe seleksionimi i mishit në pjesë anatomike, në gjashtë pjesë kryesore shpatulla, bërxolla, pançeta, kofsha, qafa dhe bishti. Ndarja në pjesë mundëson lehtësinë në përpunime të mëvonshme. Më pas bëhet ndarja e mishit nga kockat, ky është një proces që ka një ndikim shumë të rëndësishëm në teknologjinë e prodhimit të sallameve. Gjatë qërimit bëhet ndarja e pjesës së muskulit nga kocka.

Kriposja - Mbas qërimit dhe seleksionimit mishi pritet në copa të vogla me peshë 150-200 gram dhe kalon nëpër kriposje. Kriposja bëhet me 3\% kripë të përzier e cila përmban në $100 \mathrm{~kg}$ kripë $997.250 \mathrm{NaCl}$ dhe $2.5 \mathrm{~kg}$ sheqer dhe $0.250 \mathrm{~kg} \mathrm{NaNO}$. Mishi kriposet nëpër tava alumini ose fuçi druri dhe futet në frigorifer në temperaturën +4 deri $+6{ }^{\circ} \mathrm{C}$ dhe qëndron për stazhionim për 24 orë. Pas hedhjes së kripës shtohen edhe kripra të tjera siç janë nitrite dhe nitratet të cilat kanë për qëllim 
ruajtjen e ngjyrës së mishit, dhe e mbrojnë atë nga mikroorganizmat por gjithashtu ndikojnë në shijen dhe aromat e sallameve.

Grirja e mishit - Qëllimi i grirjes së mishit për sallam është shkatërrimi i indeve gjë që lehtëson proceset e mëtejshme, si p.sh shkurtohet koha e kriposjes, kripa shpërndahet më uniformisht, rritet hidrofiliteti i mishit dhe kjo çon në rritje të shkallës së asimilimit të produktit. Për sallame të ndryshme shkalla e copëtimit është e ndryshme. Grirja bëhet në makinat grirëse, të cilat përveç grirjes kryejnë edhe shtypjen dhe prishjen. Si rezultat i fërkimit temperatura në grirëse shkon gati $8-9^{\circ} \mathrm{C}$. Kjo rritje e temperatures është e padëshirueshme. Gjatë grirjes, si rezultat i copëtimit dhe shtypjes së mishit vihet re edhe rrjedhja e një sasie të vogël lëngu ndërqelizor. Prandaj, mishi që kalon në grirje duhet të jetë i stazhionuar dhe duhet të mbahet në temperaturën 4-6 ${ }^{\circ} \mathrm{C}$. Shkalla e copëtimit në makinën grirëse varet nga numri i sipërfaqeve prerëse dhe diametri i vrimave.

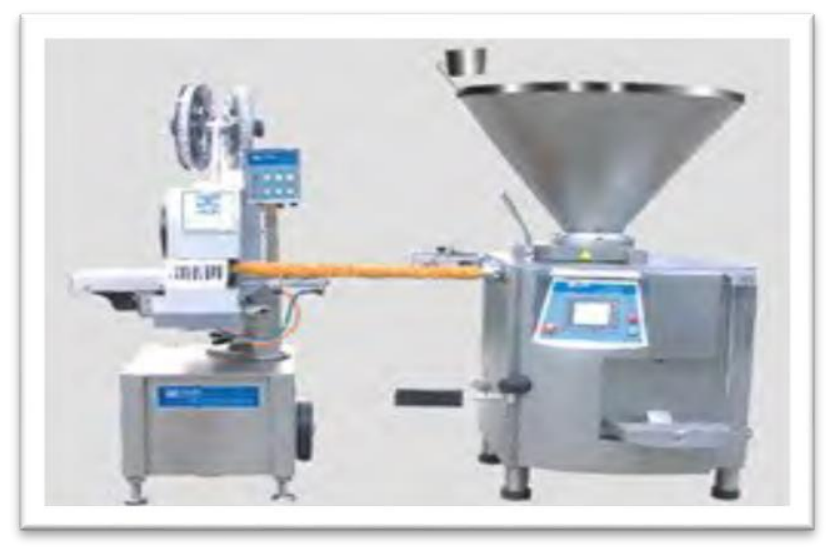

Figura 28. Lloj makine për grirjen e mishit që shërben si lënd eparë për prodhimin e sallamave.

Përgatitja e pratit - Përgatitja e pratit është një nga operacionet kryesore të prodhimit të sallamit. Prati është një masë mishi e copëtuar shumë imët që shërben si lëndë lidhëse kryesore në përgatitjen e brumit të sallamit. Ai i jep prodhimit të gatshëm të sallamit lëngshmëri, konsistencën e duhur, erën dhe shijen e këndshme. Nga cilësia e përgatitjes së pratit varet direkt rrezja dhe cilësia e produktit të gatshëm të sallamit. Nga shkatërrimi i indeve dhe proteinave të mishit rritet hidrofiliteti i tij d.m.th aftësia për të thithur dhe mbajtur ujin sa më shumë të jetë e mundur gjë që rrit cilësinë e pratit dhe për rrjedhojë edhe cilësinë e sallamit.( Donnelly, Fiona. 2011). 


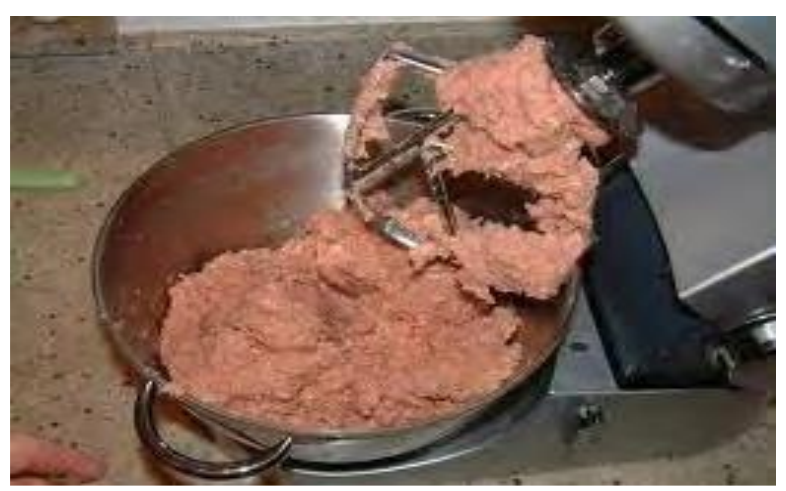

Figura 29. Makineria për përgaditjen e pratit.

Përgatitja e erëzave - Erëzat dhe lëndët e tjera ndihmëse përdoren në prodhimin e sallamit para përgatitjes së tyre me anë të bluarjes grirjes dhe shtypjes peshohen me saktësi dhe vendosen në enë të veçanta sipas recepturës për çdo lloj sallami. Erëzat që futen në prodhim duhet të plotësojnë të gjitha kushtet higjenosanitare dhe organoleptike siç përshkruhen në standardet shtetërore. Me qëllim që të shpërndahen në mënyrë uniforme me masën e pratit dhe mishin e grirë gjatë procesit të përgatitjes së brumit erëzat treten (hollohen) më parë në ujë të ftohtë. (Pegg RB, Shahidi F.2006)

Përgatitja e brumit për sallam - Gatimi i brumit të sallamit bëhet në bazë të recepturës që është e veçantë për çdo lloj salami dhe përcakton raportin sasior të pjesëve përbërëse të tij. Recepturat krijohen në bazë të një praktike shumëvjeçare të prodhimit duke respektuar parimet bazë të prodhimit si: raporti pjesëve kimike përbërëse të sallamit (proteinë:yndyrë:ujë). Raporti më i mirë proteinë yndyrë është ai 1:1, sasia e yndyrës në sallam nuk duhet të jetë më e lartë se $20 \%$ e peshës së sallamit, sasia e ujit duke qenë se ndikon në cilësinë dhe vlerën ushqimore të sallamit duhet hedhur jo më shumë se në masën e lejuar.

Brumi përgatitet në makinën përzierëse ose brumë gatuese në bazë të kësaj radhe pune: së pari hidhet prati i peshuar sipas recepturës bëhet një përzierje e shkurtër dhe në të shtohen erëzat në bazë të recepturës së holluar në ujë që të shpërndahet në mënyrë uniforme. Përzierja e tyre vazhdon për 2-3 minuta. Pastaj, shtohet mishi i grirë dhe në fund dhjami (n.q.s e përmban receptura). Përzierja vazhdon 5-10 minuta deri sa të krijohet një masë homogjene, viskoze, e ngjitshme dhe plastike që gjatë përzierjes nuk shkëputet nga përziersit e makinës. Brumi i përgatitur, zbrazet nëpër tava ose enë në formë vaske, dhe kalon në mbushje. 
Mbushja e brumit për sallam - Brumi i gatshëm i përgatitur në makinën brume gatuese sipas recepturës kalon në mbushje ku futet në cipat mbështjellëse natyrale ose artificial sipas llojit të sallamit. Mbushja e mbështjellëseve bëhet me dorë ose me makinë.

Lidhja e sallamit - Ky proces ka rëndësi për ti dhënë atyre formën e duhur, për ti dhënë rezistencë mbështjellëses për të bërë proporcionale pjesët njëra nga tjetra si dhe për të rregulluar fortësinë e mbushjes. Lidhja e sallamit bëhet me spango ose me fill pambuku sipas llojit të asortimentit.

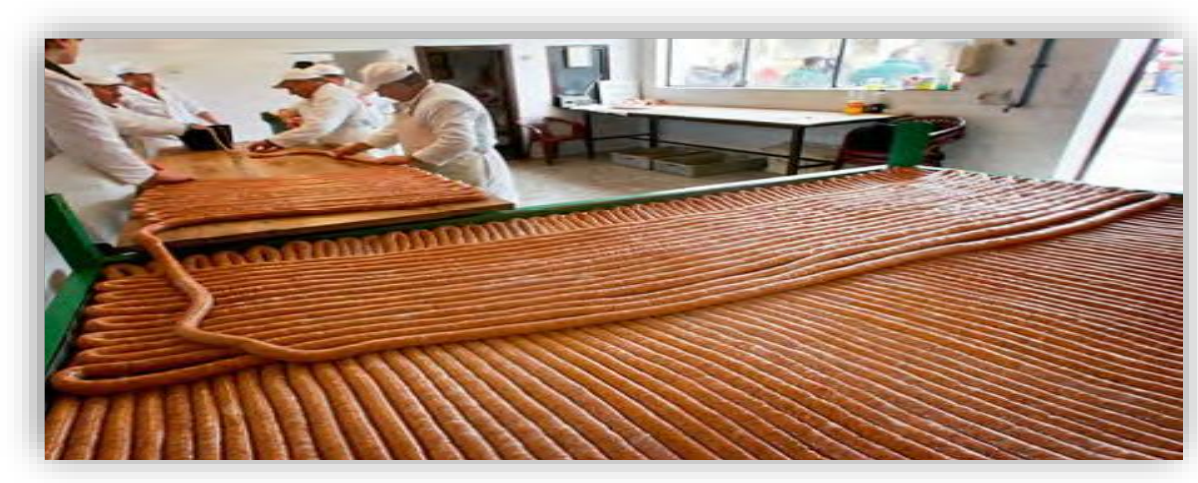

Figura 30. Mbushja e një lloji sallamit në mënyrë automatike.

Varja dhe përpunimi termik - Sallamet e lidhur ose të përdredhur, varen në shkopinj në mur sipas llojit të sallamit. Renditja e tyre bëhet në formën e gurësve të shahut në mënyrë që të bëhet $\mathrm{i}$ mundur qarkullimi më i mirë i ajrit.

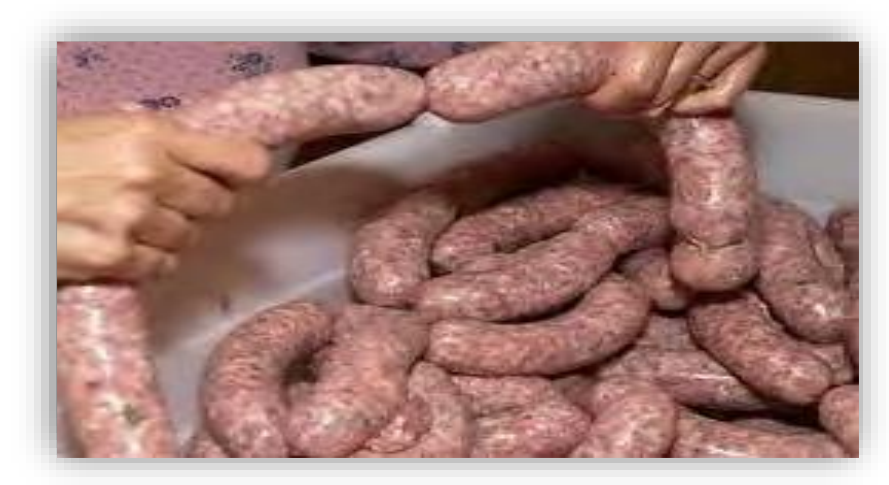

Figura 31. Lidhja e sallamit në formën përfundimtare.

Përpunimi termik i sallameve - Është proces përfundimtar dhe një nga proceset më të rëndësishme në prodhimin e sallamit. Ai përmbledh këto operacione: qëndrimin, pjekjen, zierjen, ftohjen, tymosjen dhe tharjen. Sallami i sapo varur në shkopinj nuk duhet të kalojë direkt në përpunim 
termik por lihet për një farë kohe në lokal me temperaturë relativisht të ulët nën $10^{\circ} \mathrm{C}$ dhe lagështi $80 \%$ nga 2-4 orë ose 4-6 orë kjo në varësi të sallamit të prodhuar.

Pjekja është procesi i përpunimit të sallamit me ajër të nxehtë, të përzier me tym. Mbas pjekjes cipa mbështjellëse thahet, bëhet transparente dhe më e qëndrueshme ndaj veprimit të mikroorganizmave. Në kohën e pjekjes fiksohet edhe ngjyra e brumit nga veprimi i nitratit. Detyra kryesore e pjekjes është koagulimi i kolagjenit të cipës mbështjellëse (zorrës), për ta bërë cipën më të qëndrueshme mekanikisht. Në të njëjtën kohë pjekja përmirëson pamjen e jashtme të produktit të gatshëm të sallamit meqense cipa mbështjellëse bëhet transparente. Koha e pjekjes varion nga 1 deri në 2.5 orë kjo në varësi të diametrit të sallamit. Pjekja konsiderohet e përfunduar kur temperatura në qendër të batonit arrin në $60^{\circ} \mathrm{C}$ për batonet me diametër jo shumë të madh, kurse për sallamet me diametër më të madh kur arrin $75^{\circ} \mathrm{C}$. Pjekja realizohet në dy faza: tharja dhe përpunimi me tym. Tharja ka për qëllim të largojë një pjesë të lagështisë nga sipërfaqja me qëllim që të lehtësohet hyrja e tymit në fazën e dytë. (Toldrá F, Nip W-K, Hui YH, 2007)

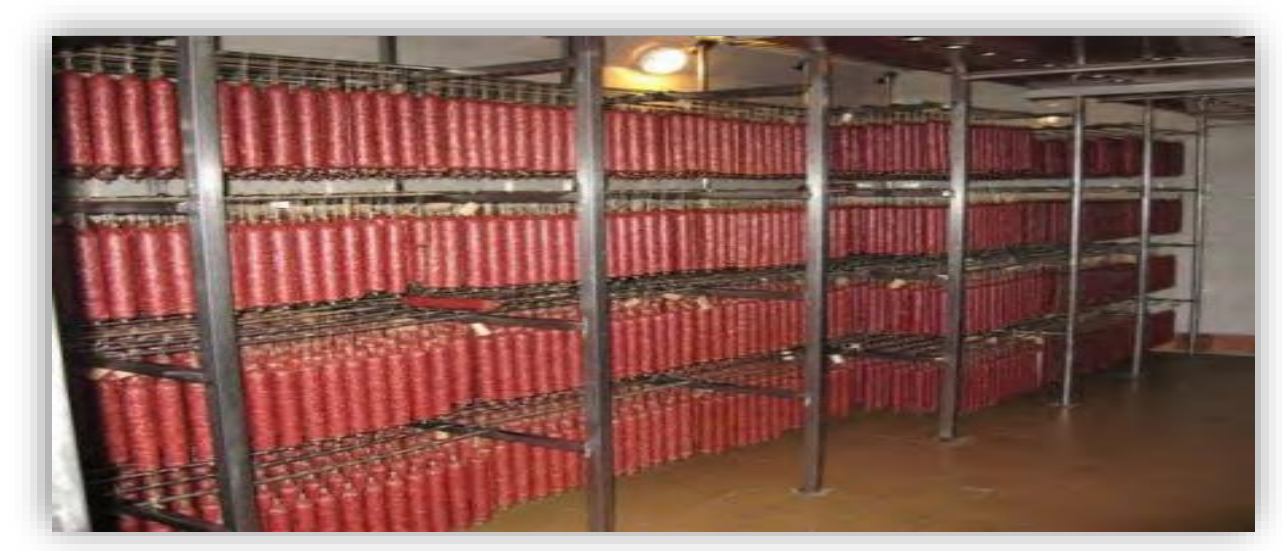

Figura 32. Mbajtëset metalike të sallamit gjatë pjekjes në furra.

Ftohja - Pas pjekjes dhe zierjes shumë e rëndësishme është ftohja e sallamit, ky proces kryhet kryesisht me lagie me ujë të ftohtë. Normalisht uji i përdorur duhet të jetë ujë i pijshëm. Ftohja bëhet me ujë në mënyrë që të mos kemi humbje në peshë gjatë avullimit të ujit. Gjithashtu nese sallamet lihen të ftohen në mënyrë natyrale atëherë në to do të mbeten bakteret termorezistente, të cilat shkatërrojnë produktin e prodhuar por edhe ndikojnë në shëndetin e konsumatorit. Ftohja me ujë bëhet për 5-10 minuta derisa temperatura në brendësi të sallamit të ketë arritur $35^{\circ} \mathrm{C}$. Pasi është mbaruar procesi teknologjik bëhet paketimi sipas llojit të sallamit, dhe bëhet ruajtja gjithmonë kushte frigoriferike. 


\subsection{Pajisjet e nevojshme gjatë përpunimit të mishit}

Në përpunimin modern të mishit, shumica e hapave të përpunimit janë mekanizuar. Në fakt, përpunimi modern i mishit nuk do të ishte i mundur pa përdorimin e paisjeve të specializuara. Paisjet e tilla janë në dispozicion për operacione në shkallë të ndryshme të përpunimit. ( Gunter Heinz and Peter Hautzinger, 2007)

Tre pjesët më të rëndësishme të pajisjeve, pavarsisht sasisë së mishit të cilët planifikojmë të bëjmë janë një termometër i saktë, një shkallë e kalibruar dhe mulliri i mishit apo grirësi. Disa nga pajisjet për përpunimin e mishit të nevojshme janë përshkruar shkurtimisht më poshtë.

Termometri - një termometër i saktë është i nevojshëm për të siguruar që mishi i papjekur të mos arrijë tempëraturen më shumë se $40^{\circ} \mathrm{F}$ gjatë përpunimit. Gjithashtu është i nevojshëm, për të matur temperaturën e brendshme të mishit të pjekur, i cili nuk duhet të jetë mjaftueshëm i ngrohtë që të mbysë çdo patogjen të mundshëm në produkt. Shumica e sallamave konsiderohen mjaftueshëm të pjekur kur arrijnë temperaturen $160^{\circ} \mathrm{F}$.

Shkalla kalibruese - kjo paisje mundëson që të kalibrohen gramet para çdo përdorimi të bëjë më të lehtë detyrën e peshimit të mishit dhe përbërësve të tjerë në recetë.

Mulliri i mishit apo grirësi - është një paisje e cila përdoret për të grirë mishin me anë të ashtuquajturit krimb ushqyes (auger) nën presion përmes një cilindri të montuar horizontalisht. Në fund të prersit gjendet një sistem prerës i përbërë nga thika në formë ylli që rrotullohen me krimbin ushqyes dhe disqeve të palëvizshme për bluarje. Pllakat e bluarjes dallojnë nga 1 deri në 13 mm. Mishi ngjeshet nga shtypësi rrotullues, shtrihet nëpër sistemin prerës dhe del jasht përmes vrimave në pllakën bluarse, pasi është prerë nga thikat në formë ylli rrotullues. Paisjet e thjeshta kanë vetëm një thikë në formë ylli dhe një pllakë bluarse. Shkalla e grirjes përcaktohet nga madhësia e vrimave në pllakën e fundit të bluarjes. Nëse mishi është i ngrirë ose është i pasur me inde lidhëse duhet të grihet në grimca të vogla, se pari duhet të grihet përmes diskut të trashë, pastaj vjen operacioni i dytë i dëshirueshëm. Në figurën e mëposhtme është paraqitur një makinë grirëse moderne. 


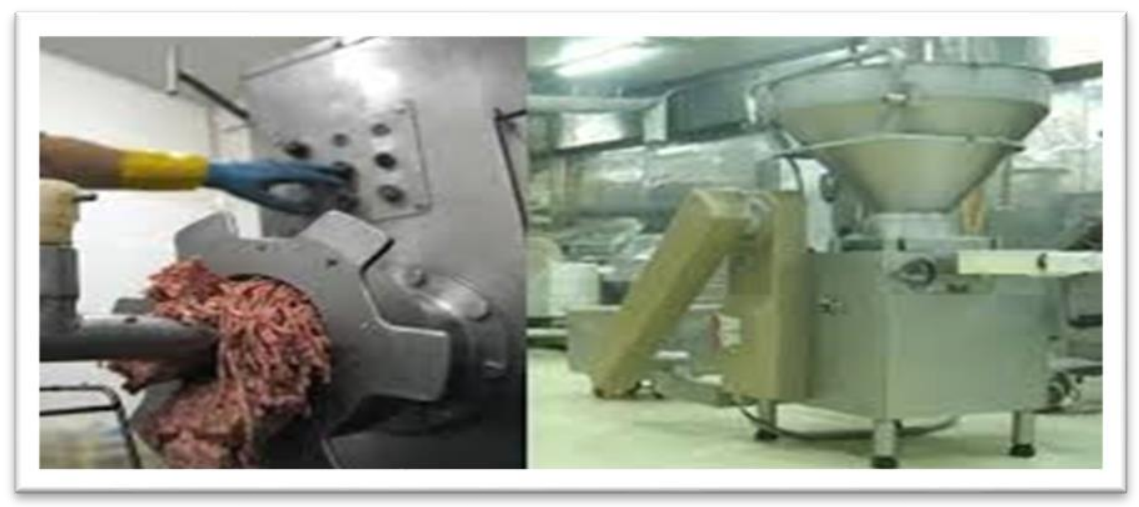

Figura 13. Makina grirëse e mishit moderne.

Prerësit në formë ene (bowl cutter) - është një paisje e cila përdoret zakonisht për coptimin e mishit, e krijuar për të prodhuar grimca shumë të vogla ose të holla të mishit dhe grimcave të yndyrës. Këta prerës përbëhen nga një enë rrotulluese horizontale dhe një grup thikash të cilat lëvizin vertikalisht me shpejtësi deri në 5,000 rpm. Ekzistojnë lloje të ndryshme të enëve me madhësi dhe vëllime të ndryshme. Këto paisje kanë një kapak të fortë mbulues. Ky kapak mbron nga aksidentet e ndryshme të cilat mund t'i hasim gjatë procesit të coptimit dhe përzierjes. Numri, forma, rrotullimi dhe shpejtësia e thikave janë faktorët kryesorë që përcaktojnë përformancën e prerësit. Gjithashtu, kjo paisje përmbanë një termometër i cili tregon temperaturën gjatë përzierjes së mishit.

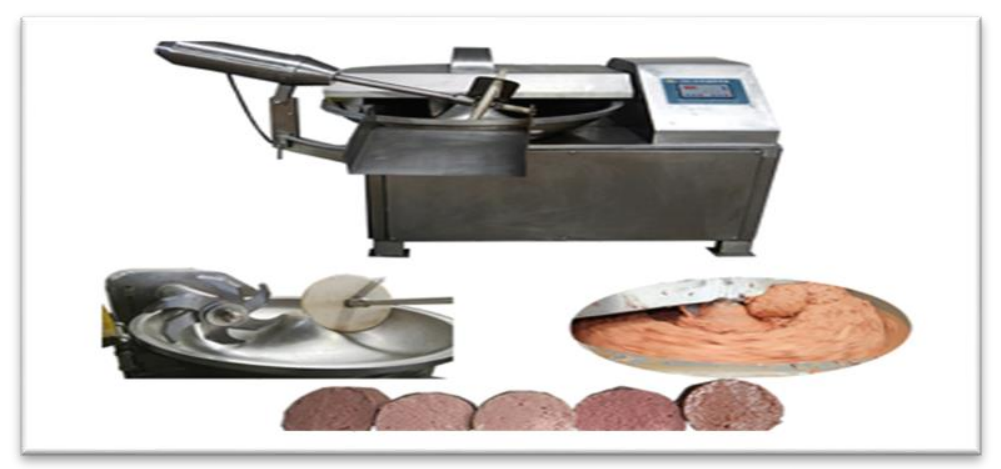

Figura 14. Prerësi në formë ene.

Makina për mbushje (sausage stuffer) - një makinë mbushëse moderne për operacione të mëdha është e dizajnuar për mbushje të vazhdueshme me vakum. Gjatë mbushjes një pjesë e konsiderueshme e ajrit të mbyllur largohet nga produkti, i cili ndihmon në përmirësimin e ngjyrës dhe strukturës së produktit përfundimtar. Këto modele zakonisht janë të pajisura me një dizajn ndarës dhe të ndërthurur si dhe një pajisje të bashkangjitur për mbështjellësit e palosur prej 
kolagjeni dhe plastike. Ky lloj i pajisje është relativisht e shtrenjtë dhe nuk përdoret tek operacionet e mesme dhe të vogla.

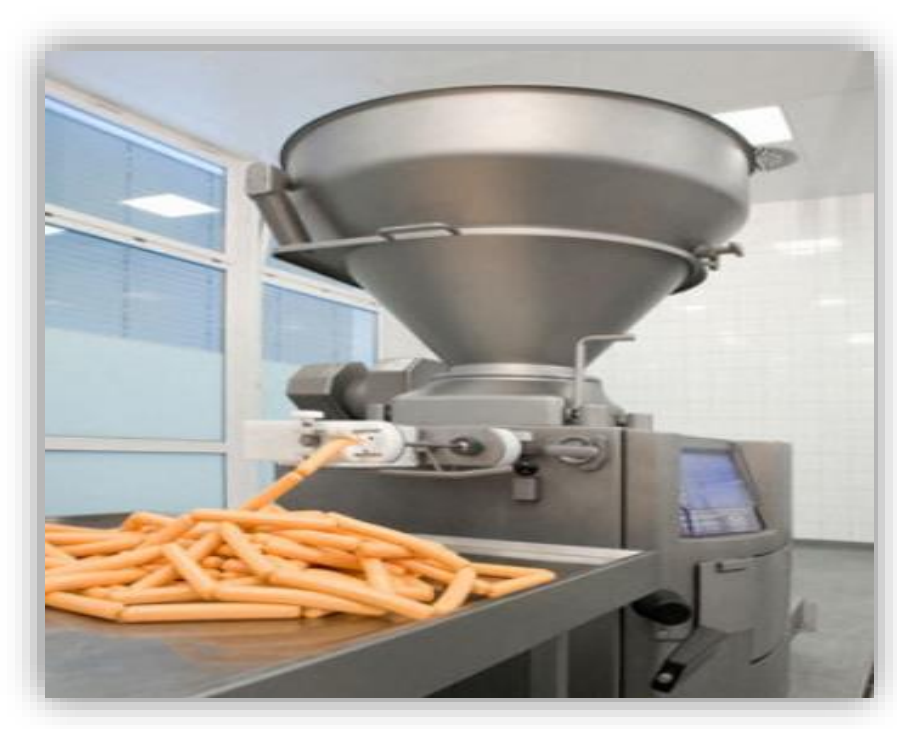

Figura 15. Makina për mbushje.

Makinat prerëse (clipping machine) - përdoren për vendosjen e kapseve metalike në skajet e sallamit si dhe zëvendëson lidhjet manuale të tij. Mund të përdoren tek mbështjellësit artificial dhe natyror si dhe mund të lidhen edhe me makinat mbushëse të cilat i përmendëm më herët. Makinerit e tilla funksionojnë duke liruar ngadalë përmbajtjen në formë shiriti nga brirët e mbushësit duke siguruar një mbushje të fortë ku segmentet e mbushësit grumbullohen në pjesë. Ku pastaj, kjo makineri mundëson që të vendosën dy kapse në të dy skajet e sallamit çka i mundëson të ndahen me lehtësi nga njeri-tjertri. Kjo makineri përdoret më shumë tek operacionet e mëdha dhe tek operacionet me kompresim të ajrit, ndërsa tek operacionet e vogla dhe të mesme nuk përdoret shumë. Në figurën e mëposhtme është paraqitur makina për prerje e kombinuar me makinën për mbushjen e sallamave dhe salsiçeve.

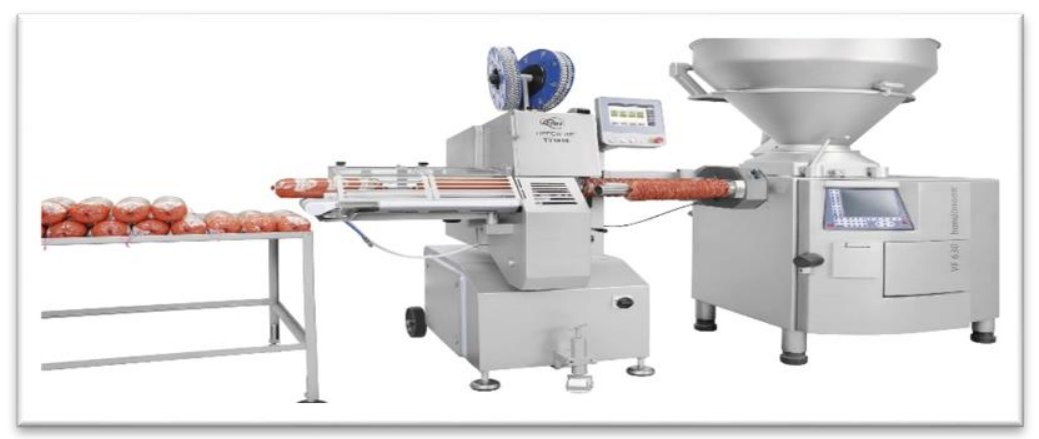

Figura 16. Makina për prerje dhe makina për mbushje e kombinuar. 
Makinerit për tymosjen e mishit (smokehouses) -Në operacionet e zakonshme dhe të thjesht të tharjes së mishit, metodat për gjenerimit të tymit përfshijnë djegien e drurëve dhe pastaj vazhdon me ngrohjen me anë të tallashit dhe drurëve të vegjël. Mirëpo, me përparimin e teknologjisë kanë ndryshurar metodat dhe teknikat e prodhimit të tymit. Dy nga metodat e përdorura në përpunimin modern përfshijnë:

$\Leftrightarrow$ Djegia/ djegia e pluhurit gjatë sharrimit - tek tymosësit modern të mishit, gjenerimi i tymit bëhet jashtë dhomës së tymosjes në një gjeneratorë të veçantë të tymit të ndezur në mënyrë elektronike apo me gazë i cili mundëson kontrollë më të mirë të sasisë së tymit dhe temperaturës së krijuar. Materiali ndezës si pluhuri i drurit (tallashi) është i zhvendosur nga kutia në zonës e djegies nga një nxitës apo tundës. Ky gjenerator ndizet me anë të një pllake në mënyrë elektrike apo me flakë gazi, ndërsa një shirit i tymit, i cili në thelb është një sprej i ftohtë uji është i vendosur në pjesën e përparme të tubit të tymit dhe shërben për pastrimin e tymit nga substancat e padeshirueshme. Kështu tymi i pasterizuar transmetohet direkt nga gjenaratori në dhomën për tymosje përmes tubit të tymit, ndërsa tallashi i djegur mblidhet në fund.

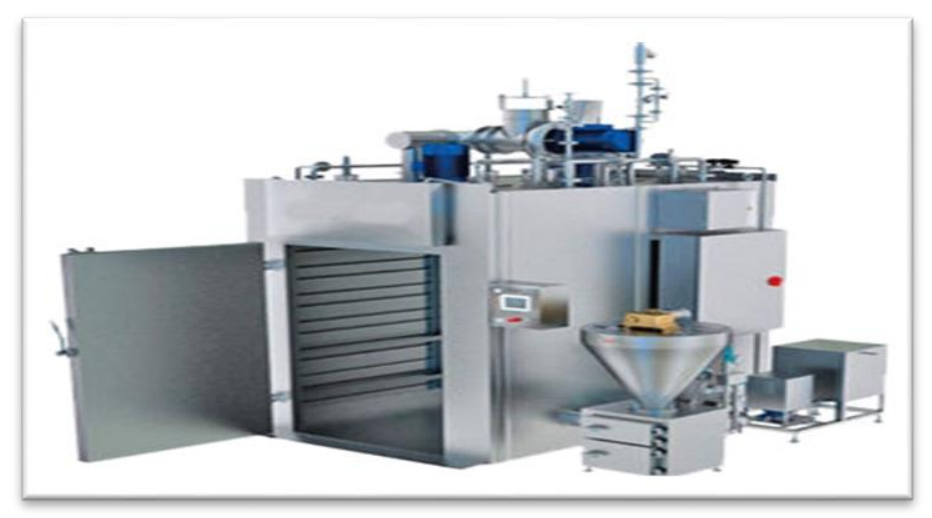

Figura 17. Dhoma për tymosjen e mishit me gjenerator të ndarë për prodhimit e tymit.

$\leftrightarrow$ Gjenerimi i tymit përmes fërkimit -lënda drunore shtypet kundër një daulle rrotulluse të shpejt i cili rezulton në një pirolizë së drurit në një interval të favorshëm të temperaturës prej $300^{\circ} \mathrm{C}$ deri $400^{\circ} \mathrm{C}$. Tymi i ndezur lehtë, i dendur dhe aromatik përmban një pjesë të madhe të substancave të dëshirueshme të tymit dhe një sasi të vogël të katranit. Pastaj, ky tym përcillet në dhomën për tymosje. Krijimi i tymit mund të fillojë dhe të përfundojë brenda sekondave. Funksionimi i këtij lloji të gjeneratorit të tymit zakonisht zhvillohet brenda sekondave. Sasia 
dhe cilësia e tymit mund të rregullohet duke ndryshuar shpejtësinë dhe kohën e rrotullimit. Meqenëse ky lloj tymi mund të prodhohet në temperatura relativisht të ulëta, ai nuk mbart sasi të mëdha të substancave të rrezikshme siç është benzopreni.

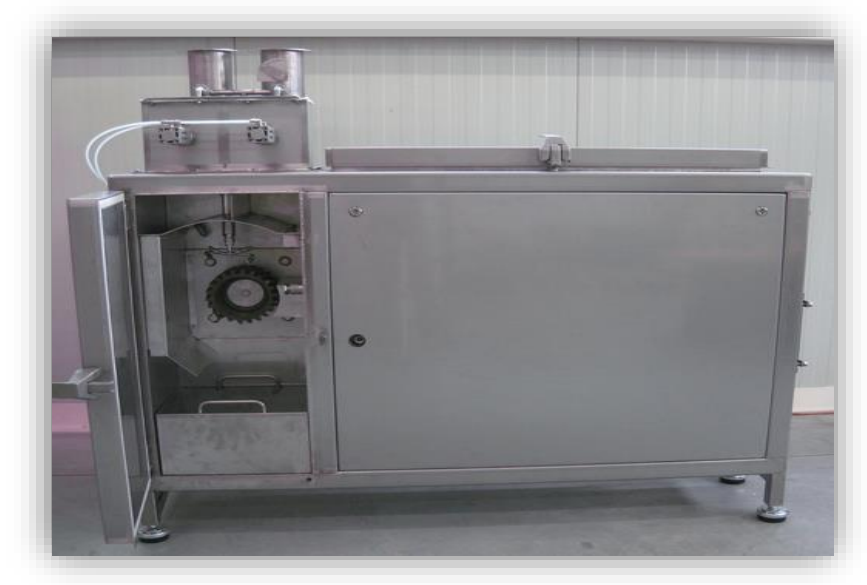

Figura 18. Gjeneratori për prodhimin e tymit me fërkim.

Pajisjet e kombinuara - objektet moderne mund t'i kombinojnë operacionet e ndryshme si tymosjen, përgaditjen dhe ftohjen e produktit të mishit në një proces të vazhdueshëm, me anë të parametrave të sistemeve të automatizuara të përziera si gjenerimi i tymit me temperaturë (deri $\left.100^{\circ} \mathrm{C}\right)$ dhe relativisht me lagështi, i cili kërkohet për tharje, tymosje apo përgaditje në avull të çfardo produkti të nevojshëm i cili mund të paracakohet. Me instalimin e njësisë frigorifike shtesë në dhomën për tymosje, është gjithashtu e mundur që të përdoret edhe për fermentim tek hapat e parë gjatë fermentimit të sallamit të fermentuar, suxhukit, proshutave ku temperatura dhe lagështia e ajrit duhet të kontrollohet saktësisht.

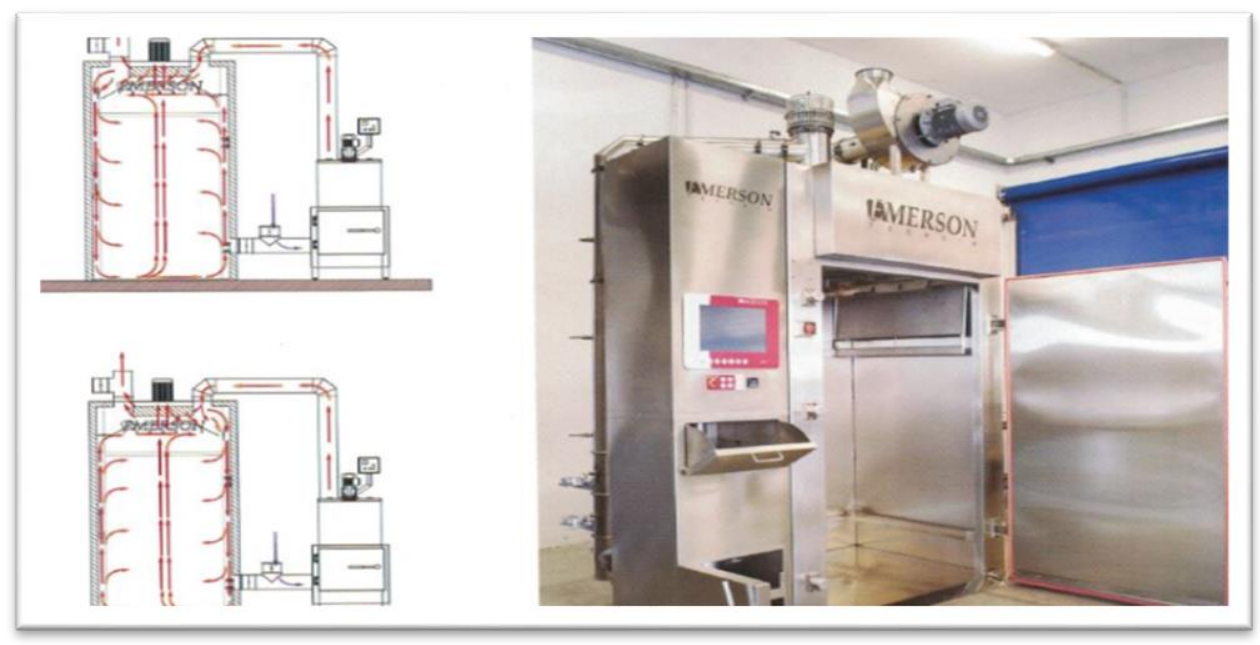

Figura 19. Gjeneratori i kombinuar. 
Injektimi $i$ shëllirës - kjo pajisje shërben për injektimin e shëllirës në mish. Shëllira është ujë i cili përmban kripë të tretur dhe nitritete të tjera, si dhe aditivë të tjerë si fosfatet, erëza, sheqer, karagjenate dhe proteina të sojës. Injektimi bëhet duke futur gjilpëra në indet muskulore. Injektimi me shëllirë përdoret kryesisht tek mishi i derrit dhe produktet e tij, mirëpo përdoret edhe tek produktet e tjera muskulore të mishit.

Këto pajisje janë të disponushme me madhësi të ndryshme nga pajisjet me manovrim manual me një gjilpërë tek operacionet e vogla e deri tek injektimet gjysmë të automatizuara me 32 gjilpëra apo edhe më shumë. Tek makinerit e mëdha sasia e injektimit të shëllirës në mish të freskët mund të përcaktohet duke paracaktuar fillimisht presionin dhe shpejtësinë.

Është e rëndësishme që të gjitha pjesët e injektorit të pastrohen plotësisht pas çdo përdorimi dhe të dezinfektohet rregullisht. Si dhe para çdo përdorimi, të gjithë tubat dhe gjilpërat duhet të pastrohen me ujë të ngrohtë pasi mund të ketë grimca të mbetura të cilat mund ta bllokojnë sistemin e gjilpërave. Pastërtia absolute është e domosdoshme pasi mikroorganizmat të ndryshëm të mbetur në sistem mund të injektohen në mish gjatë operacionit.

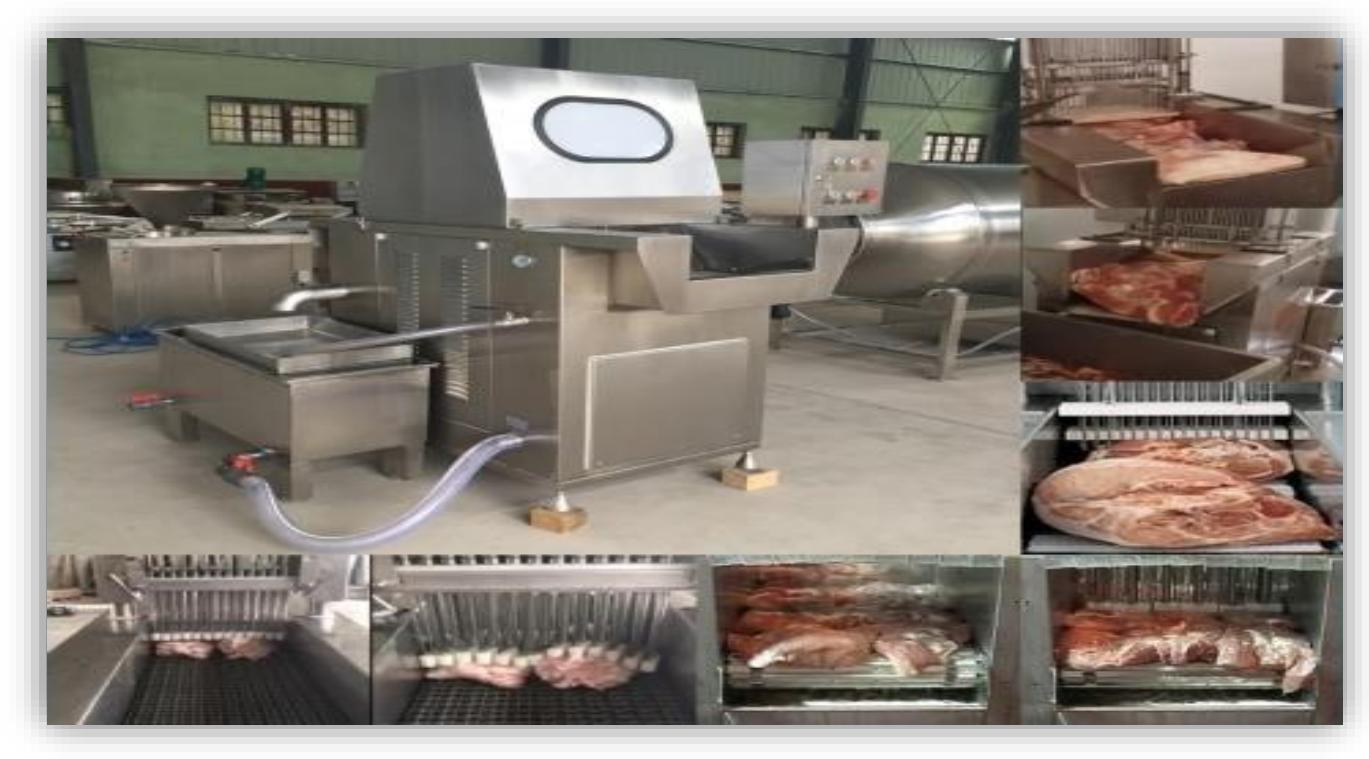

Figura 20. Makineria për injektimin e shëllirës në mish.

Tumbullat apo masazhuesit e mishit - Tumbullat përdoren për përpunimin e produkteve të mishit që janë muskulë i plotë apo tulë. Makinat e tilla ngjajnë në parim me një miker betoni në formë daulleje rrotulluse me lopata prej çeliku brenda të cilat e lëvizin mishin ngadalë duke shkaktuar kështu një efekt masazhi mekanik. Ky proces mekanik ndihmohet nga shtimi i kripës dhe fosfateve 
për të arritur shpërndarjen e barabartë të shëllirës si dhe çliron proteinat muskulore nga indet e mishit (nxjerrjen e proteinave). Substancat proteinike gjysmë të lëngshme bashkohen me copat e mishit në mënyrë të qëndrueshme gjatë trajtimit të mëvonshëm të nxehtësisë. Për arsye higjienike është e rëndërsishme të vendoset tumbulla nën $10^{\circ} \mathrm{C}$ për të shmangur rritjen e mikrobeve gjatë kohës së masazhimit. Në raste specifike rekomandohet që tumbulla të operojë në frigorifer ose brenda një dhome të ftohtë në $-1^{\circ} \mathrm{C}$, pasi këto temperatura janë më të mira për nxjerrjen e proteinës së tretshme nga muskujt e mishit.
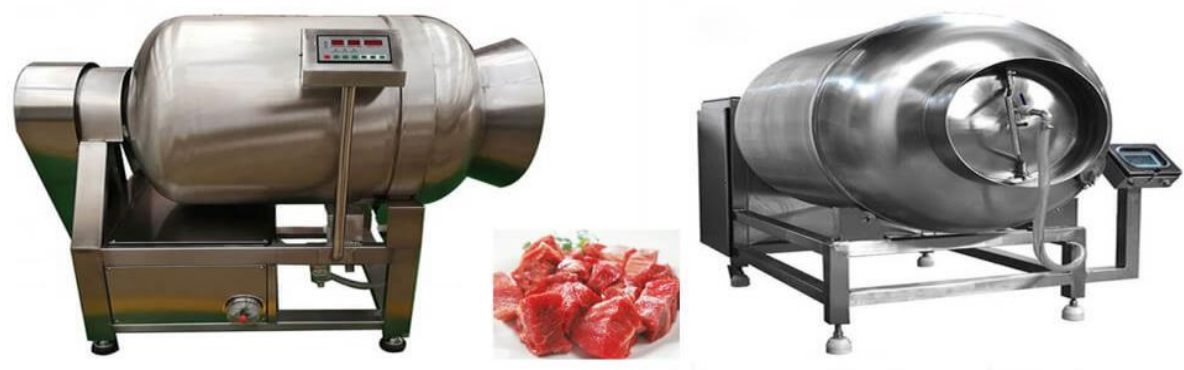

Figura 21. Masazhuesit e mishit.

Makineria për paketim me vakum - për paketim me vakum produkti i mishit duhet të vendoset në qese me vakum. Largohet ajri nga qesja me anë të makinerisë dhe pastaj qesja mbyllet. Makinerit speciale të paketimit me vakum mund të operojnë me të ashtuquajturen ndezje gazi, ku injektohet një përzierje gazi pas largimit të ajrit. Atmosfera e tillë me gaz mbrojtës brenda qeses së produktit pengojnë rritjen e baktereve dhe stablizojnë ngjyrën e mishit. Përzierja e gazit zakonisht përmanë $\mathrm{CO}_{2}$ dhe $\mathrm{N}_{2}$.
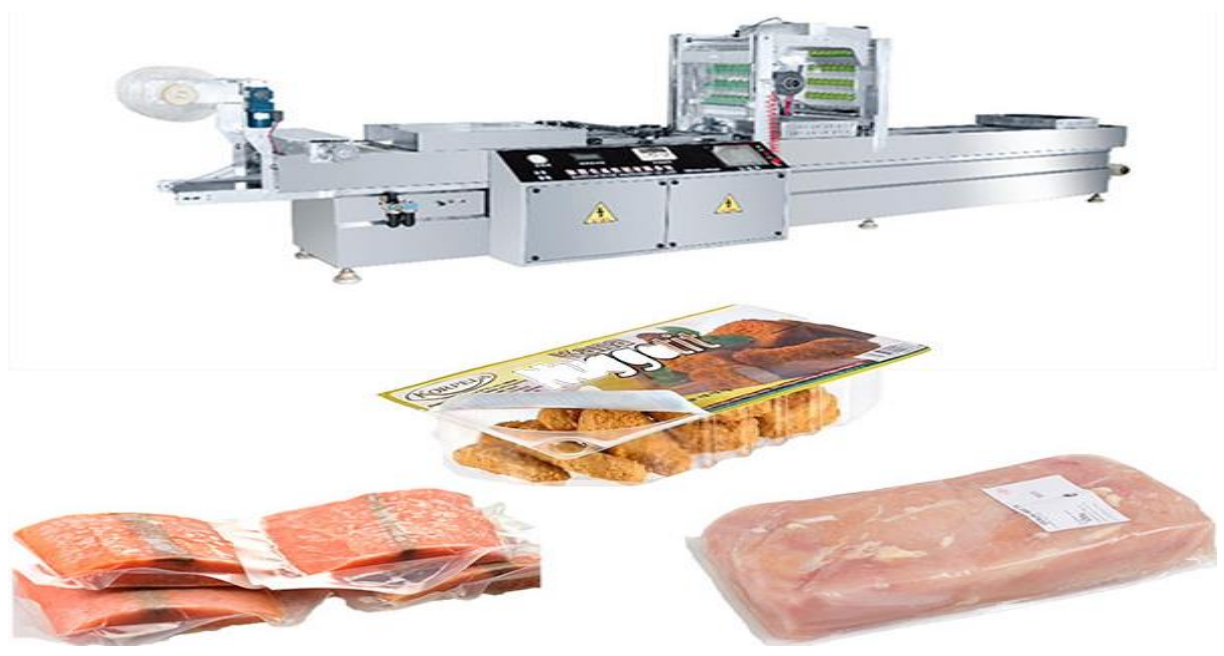

Figura 22. Makinera për paketimin e mishit me vakum. 
Makina emulsifikuese (mulliri koloid) - emulsifikuesi shërben për përgaditjen e emulsioneve shumë të imëta të mishit. Pjeset e tij funksionale janë një pllakë e shpuar të cilës i bashkangjiten dy tehe rrotulluese të rotorit. Pranë teheve gjendet një pompë centrifugale e cila e shtynë mishin drejt pllakës së shpuar. Shumica e emulsifikuesve janë njësi vertikale. Në krahasim me prerësin në formë ene, emulsifikuesi operon me shpejtësi shumë më të lartë, duke prodhuar një përzierje më të imët në formë emulsioni. Gjithashtu emulsifikuesi është i përshtatshëm për prodhimin e produkteve gjysmë të përpunuara siç janë emulsionet nga lëkura e derrit.

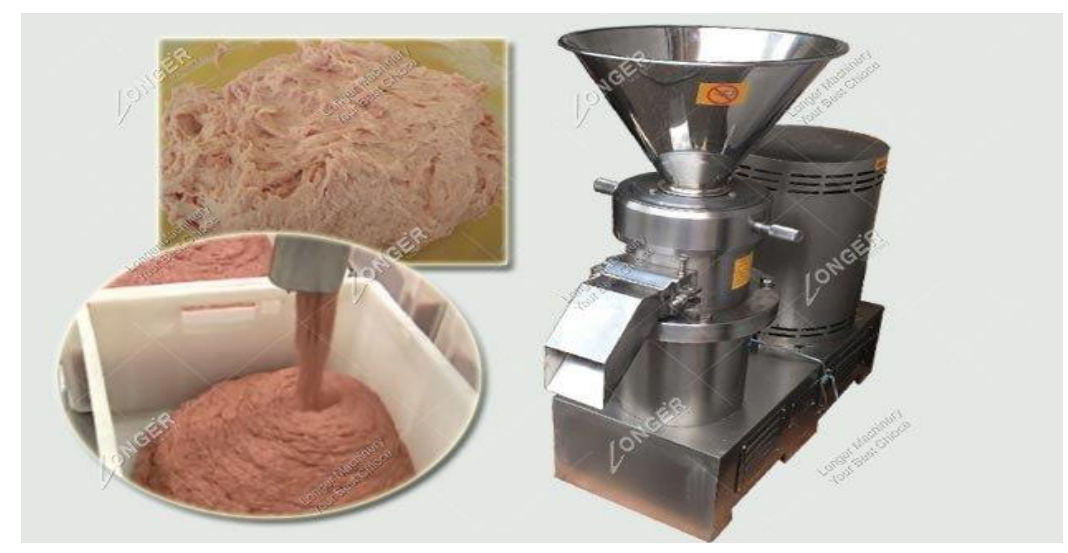

Figura 23. Makina emulsifikuese (mulliri koloid).

Makinerit e dëborës - në këto makineri fluskat e akullit prodhohen vazhdimisht nga uji i pijshëm. Akulli është i nevojshëm në përpunimin e mishit për disa lloje të produkteve të mishit. Uji i shtuar në formë akulli është një përbërës i rëndësishëm për të përmirsuar zgjidhjen e proteinave dhe për të mbajtur tempraturën e mishit të ulët. Makinerit e dëbores me pajisje të dezinfektimit UV të integruar me ujë janë të disponueshme në zonat me furnizim të ujit të pasigurt.

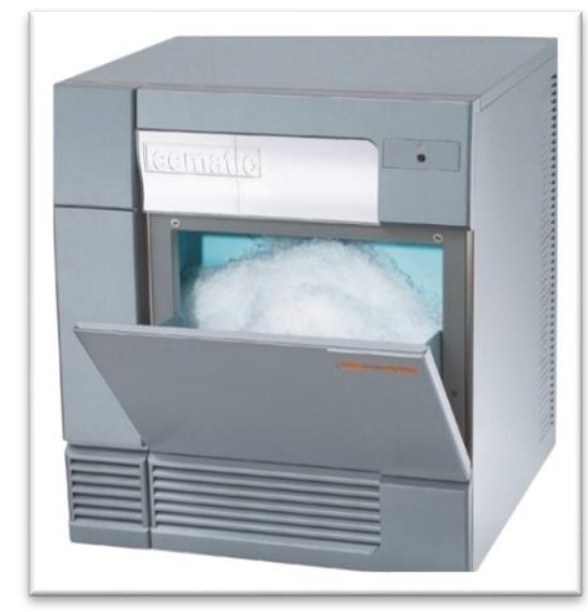

Figura 24. Makineria e dëborës. 
Prerësi i mishit të ngrirë - qëllimi i prerjes së copave të mishit në pjesë më të vogla është që të bëj mishin e ngrirë më të përshtatshëm për proceset e coptimit, bluarjes etj. Ekzistojnë dy lloje të makinave për prerjen e mishit të ngrirë, që punojnë me thika të vendosura në mënyrë vertikale ose me bateri rrotulluese ku gjenden të bashkangjitura thika të mbrehta. Në rastin e parë të makinerisë koka e thikës operon në mënyrë hidraulike ku edhe produktet më të ngrira mund të priten në copa të vogla. Ndërsa, tek makinerit me prerës rrotullues operon sipas parimit të gdhendjes nga copat e mishit të ngrirë. këto makineri mund të presin prej copave të mëdha të mishit të ngrirë e deri të ato më të voglat.
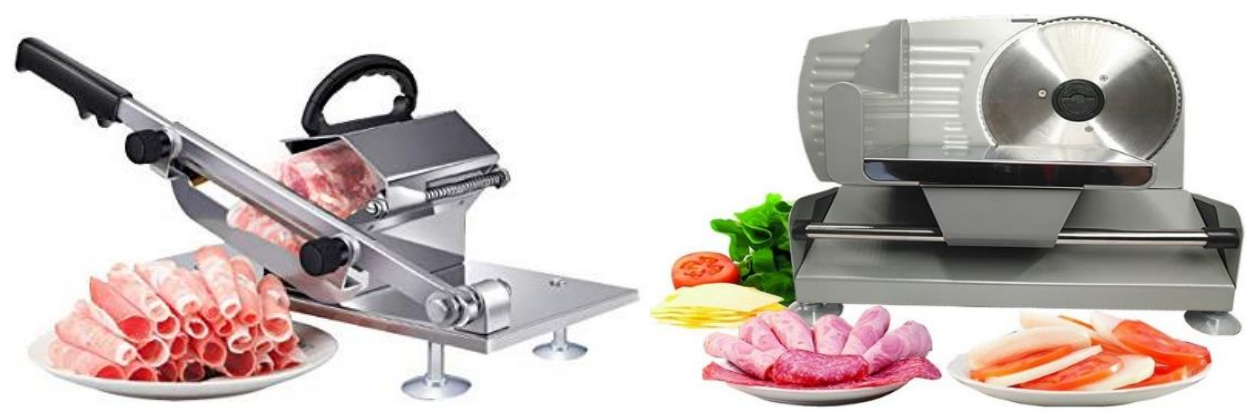

Figura 25. Makinerit për prerjen e mishit të ngrirë: prerësi me thika vertikale dhe prerësi me thika rrotulluese.

\subsection{Metodat pët testimin e mishit dhe produkteve të tij}

Për t'iu përgjigjur kërkesave të sigurisë, mbrojtjen e shëndetit të konsumatorëve dhe mbështetjen e vet reputacionit të brendit, prodhuesit e mishit duhet të garantojnë sigurinë e produkteve të tyre në çdo fazë: nga fermat dhe pajisjet e përpunimit e deri të qendrat e shpërndarjes.

Testimi i produkteve duhet të përfshijë standarde në përputhje me rregullat e përpunimit si dhe tregun e destinuar. Këto teste jane :

\section{Testet mikrobiologjike:}

8o Organizmat indikatorë: koliformat, speciet Enterobakter, Staphylococcus, bakteret e aciditetit laktik, maja dhe myku,

so Patogjenet: Salmonella, Campylobacter, listeria, E. Coli, stec.

\section{Testet Fiziko-kimike:}

\&o Ndotësit: pesticidet, antibiotikët, ilaçet, mbetjet veterinare, alergjent të metaleve të rënda, përfshirë edhe glutenin,

8o Pasuesit: hiri, yndyra, proteina, kripa dhe lagështia. 
Testet e vlerave ushqyese dhe treguesit e cilësisë:

8o Panelet e vlerave ushqyrjese të plota: kaloritë, karbohidratet, yndyrat dhe acidet yndyrore, 8o Mineralet: kalciumi, hekuri, fosfatet dhe nitrati i natriumit,

so Përqindja e kockave: uji i shtuar, dhe fosfatet e shtuara. "(FAO, 1990) 


\section{DEKLARIMI I PROBLEMIT}

Industria e mishit dhe prodhimeve të tij në Kosovë, jetësohet përmes kompanive të ndryshme të cilat janë ngritur me qellim që përmes prodhimit të produkteve të mishit në përgjithësi, si dhe të sallamave në veçanti, t'i ofrojnë konsumatoreve laramani të produkteve si për nga forma ashtu edhe për nga shija e tyre. Gjatë prodhimtarisë në këto kompani, patjetër që janë të obligueshme që t'i nënshtrohen standardeve ndërkombëtare të ushqimit, siç është Codes Alimentarius si dhe rregulloreve ligjore vendore, siç janë Udhëzimet Adminstrative të Kosovës. Kjo bëhet me qellim që këto produkte të kenë cilësi dhe siguri për konsumatoret të cilët i konsumojnë këto produkte.

Për të përmbushur obligimeve ligjore të përmendura më lartë, kompanitë industriale për prodhimin e sallamave që duhet t'i përmbahen procedurave të caktuara të teknologjisë së prodhimit të sallamave. Përmbajtja e procedurave të caktuara teknologjike, patjetër që imponon që këto kompani të fusin në procesin e prodhimit lloje të reja të makinave, aplikimin e aditivëve të rinj kimikë, llojeve të reja të mbeshtjellesve, materialeve të paketimit si dhe te inkorporojnë në këtë teknologji edhe konceptet e reja të procedurave themelore për prodhimin e sallamave.

Krahas kësaj, bazuar në standardet ligjore, sallamat e prodhuara në këto kompani vendore, janë të detyruara që të aplikojnë metodat e vetkontrollit të prodhimeve të tij, si dhe njëkohësisht këto prodhime i nënshtrohen edhe kontrollave dhe analiza nga institucionet vendore me qellim të verifikimit të kualitetit në përbërje si dhe në aspektin mikrobiologjik, me qellim të ngritjes së kualitetit dhe të sigurohet siguria e këtyre prodhimeve.

Në këtë punim ne kemi ndërmarrë një hap modest për të hulumtuar procedurat e teknologjisë së prodhimit të sallamave në kompaninë për prodhimin dhe përpunimin e mishit SHPK "Sole Kosova”, me seli në Fushë Kosovë duke synuar që të përqendrohemi në 2 pika kryesore:

1. Zbatimi i procedurave standarde të teknologjisë së prodhimit të sallamave;

2. Verifikimin e treguesve të cilesisë së sallamave të prodhuara, përmes analizave fiziko-kimike dhe mikrobiologjike, të realizuar në Institutin Kombërtar të Shëndetësisë Publike të Kosovës (IKSHPK) gjatë muajit Shtator të vitit 2019. 


\section{METODOLOGJIA}

Hulumtimi është bërë në gjatë muajit Shtator të vitit 2019 në fabrikën për përpunimin e mishit dhe prodhimeve të mishit SHPK "Sole Kosova” me seli në Fushë Kosovë. Përndryshe kjo kompani ofron produkte të ndryshme të mishit, të pulës, viçit, qumështit, pemëve dhe perimeve dhe mallërave të ndryshme.

\subsection{Metodologjia e prodhimit te sallamave në fabrikën SHPK "Sole Kosova"}

Ecuria e prodhimit të sallamit në baze të procedurave teknologjike për prodhimin e sallames do të pershkruhet në faza të caktuara :

- Si lëndë e parë për podhimin e sallames së gjedhit (parizer i viçit) është përdorë mish dhe dhjami i gjedhit, ndërsa për prodhimin e sallames së pulës (parizer pule) është përdorë mishi dhe dhjami i pulës. Ky mish merret nga konteniret me ftohje dhe magazinohen në Depon me ngrirje të thellë $\geq-18$. Gjatë pranimit te mishit, janë marrë regjistruar në skederët për pranimin e mallit, informacionet në lidhje me origjinën, datën e skadencë dhe të dhëna të tjera që kanë të bëjn dhe me cilësinë e mishit. Gjatë kohës së ruajtjes së misht dhe yndyres se mishit, është bërë monitorimi i temperaturës nëpërmjet formularit përkatës.

- Pas marrjes së mishit si lënde e parë nga depoja e ruajtjes, është bërë shkrirja e mishit dhe yndyrës së pulës. Këto janë lënë të shkrihen për 12 orë në temperaturë të ambientit afro 10 ${ }^{\circ} \mathrm{C}$. Pasi shkrirja e lëndës së parë ka përfunduar është bërë copëtimi dhe bluarja këtij mishi me makineri në repartin e posaqëm për këtë fazë. Masa e përftuar pas bluarjes ka kaluar nëpërmjet karrelave dhe është marrë dhe transportuar në makinën përzierse (kuter).

- Brumi i përftuar ka kaluar nëpërmjet karrelave në makinerinë e mbushjes e cila relazohet në zorrë minerale apo natyrale varsisht nga produkti që prodhohet. Pas mbushjes është bërë matja e karrelave dhe vendosja në furrat e pjekjes. Temperatura e nevojshme për këto produkte duhet të arrije $72^{\circ} \mathrm{C}$ në brendësi të produkti për një kohë $60 \mathrm{~min}$. Procesi pjekjes monitorohet nëpërmjet formularit sipas llojit të produktit. 
- Pas përfundimit të procesit të pjekjes është bërë një ftohje e lehtë përmes dusheve deri sa të bie temperatura afro $30^{\circ} \mathrm{C}$, pastaj ka kaluar në dhomën e ftohjes për maturim në temperatur $0-5{ }^{\circ} \mathrm{C}$, ku ka qendruar per 12 orë.

- Paketimi i produktit është bërë në kuti kartoni ku edhe janë vendosë të gjitha informacionet për produktin si: emri i produktit, prodhuesi, përmbajtja, data e skadencës dhe kushtet e rujtjes.

- Se fundmi produkti është vendosur në frigoriferin e ruajtes së produktit të gatshëm në temperaturë $0-5^{\circ} \mathrm{C}$.

- Gjate transportit, produktet janë transportuar me automjet frigorifer me mbajtje të temperaturës nga $0-5^{\circ} \mathrm{C}$.

\subsection{Metodologjia e mostrimit te mostrave}

Me qellim të verifikimit të kualitetit të sallamave të prodhura (parizereve), ne kemi marrë 2 mostra dhe atë:

Për mostrim të kualitetit të sallamave të prodhuara janë marrë:

- Një moster të sallames së gjedhit (parizer viçi) në peshë prej 400 gram të cilat janë përzgjedhë sipas rastësisë, të mbështjellur në kuti kartoni (paketimi i saj), janë vendosë në frigorifer të dorës në temperaturë +4 gradë celsius dhe

- Një moster të sallames së pulës (parizer pule) në peshë prej 400 gram, janë mbështjellur në një kuti të kartonit (paketimi i saj), janë vendosë në frigorifer të dorës në temperaturë +4 gradë celsius.

Transporti i sallamave është bërë në temperaturën e frigoriferit të dorës dhe dorëzimi i këtyre mostrave është bërë në laboratoret testues të Institutit Kombërtar të Shëndetësisë Publike të Kosovës (IKSHPK) gjatë muajit Shtator të vitit 2019. 
Analizat e mostrave Parizer pule 400 gr. dhe parizer viçi 400 gr. kanë të bëjnë me analizat fizikokimike dhe analizat mikrobiologjike .

\subsection{Metodologjia e analizave te mostrave}

\subsubsection{Analizat fiziko - kimike}

Për të realizuar mostrat në aspektin fiziko - kimik, janë testuar:

Parametrat organoleptik që përfshijnë:

$>$ Konzistencën,

$>$ Ngjyrën,

$>$ Erën dhe shijen dhe

$>$ Përmbajtjet e huaja.

Parametrat kimik që përfshijnë:

$>$ Yndyrën sipas metodës standarde: AOAC 960.39;

$>$ Hirin sipas metodës standarde: AOAC 920.153;

$>$ Nitritet sipas metodës standarde: AOAC 973.31;

> Kripa sipas metodës standarde: AOAC 935.47;

> Proteinat sipas metodës standarde: AOAC 981.10;

$>$ e H2O sipas metodës standarde: AOAC 950.46;

\subsubsection{Analizat mikrobiologjike}

Për të realizuar mostrat në aspektin mikrobiologjik janë testuar prania e këtyre mikroorganizmave:

Salmonella sipas metodës standarde: ISO 6579:2002;

> Staphylococcus aureus sipas metodës standarde: ISO 6888-2:1999;

$>$ Escherichia coli sipas metodës standarde: ISO 16649-2:2001;

> Bakteret koliforme sipas metodës standarde: ISO 4832-2006;

$>$ Numri i përgjithshëm i baktereve të gjalla mezofile sipas metodës standarde: ISO 4833:2003; 


\section{PREZANTIMI DHE ANALIZA E REZULTATEVE}

\subsection{Prezantimi dhe analiza e razultateve rreth Metodologjise se prodhimit te sallamave në fabrikën SHPK "Sole Kosova"}

Bazuar në përcjelljen e ecurisë së procedurave teknologjike për prodhimin e sallamave gjatë procesit prodhues mund të vërejmë se në përgjithësi, i tërë procesi ka rrjedhur konform procedurave të përgjithshme për prodhimin e sallameve.

Në veçanti vlen të përmendet:

$\checkmark$ Si lëndë e parë për prodhimin e sallamës së gjedhit (parizer i viçit) është përdorë mish dhe dhjami i gjedhit ndërsa për prodhimin e sallamës së pulës (parizer pule) është përdorë mishi dhe dhjami i pulës i cili është ngrirë në temperaturat adekuate - 18 gradë Celsius si dhe është regjistruar sipas procedurës e cila zbatohet për origjinën, datën e skadencës etj.

$\checkmark$ Procedura e shkrirjes së mishit dhe dhjamit është bërë në kohëzgjatje prej 12 orë në temperaturë të ambientit afro $10^{\circ} \mathrm{C}$, që përkon me standardet për shkrirjen e mishit.

$\checkmark$ Copëtimi dhe bluarja e mishit është realizuar në repartin e posaqëm për këtë me makinën për bluarje dhe pastaj nëpërmjet karrelave është transportuar në makinën përzierse (kuter).

$\checkmark$ Brumi i përftuar ka kaluar nëpërmjet karrelave në makinerinë e mbushjes së zorrëve minerale apo natuyrale dhe pastaj sallamat janë vendosur në furrat e pjekjes, duke përdorë temperaturat e nevojshme për këto produkte e cila duhet të arrije $72{ }^{\circ} \mathrm{C}$ në brendësi të produktit për një kohë 60 min si dhe procesi i pjekjes është monitoruar duke respektuar normat ligjore për këtë çështje.

$\checkmark$ Pas përfundimit të procesit të pjekjes është bërë një ftohje e lehtë përmes dusheve deri sa të bie temperatura afro $30{ }^{\circ} \mathrm{C}$, pastaj ka kaluar në dhomën e ftohjes për maturim në temperaturë $0-5{ }^{\circ} \mathrm{C}$, ku ka qëndruar për 12 orë që përkon me metodologjinë dhe standardet ligjore të përcaktuar për ruajtjen e këtyre produkteve.

$\checkmark$ Paketimi i produktit dhe etiketimi i tij është bërë konform rregulloreve, duke përfshirë datën e skadencës dhe kushtet e rujtjes. 
$\checkmark$ Ruajtja e produkteve është bërë në kushtet e frigoriferit në $0-5^{\circ} \mathrm{C}$, sipas standardeve.

Marrë në përgjithësi, metodologjia e përdorurë gjatë teknologjisë së prodhimit të sallamave, është brenda standarteve ligjore që e rregullojnë këtë çeshtje, dhe kjo patjetër që është mundur të realizohet edhe përmes paisjeve adekuate të cilat përdoren për prodhimin modern dhe të sigurtë të sallamave, si produkte të rëndësishme të mishit.S

\subsection{Prezantimi dhe analiza $\mathrm{e}$ razultateve rreth analizave fiziko- kimike dhe mikrobiologjike te mostrave të derguara në laboratorë}

\subsubsection{Rezultatet e analizave për produktin parizier pule 400GR}

\subsubsection{Rezultatet e analizave fiziko - kimike}

\begin{tabular}{|c|c|c|c|c|}
\hline \multirow[t]{2}{*}{ Parametrat e testuar } & \multirow[t]{2}{*}{ Metoda standarde } & \multicolumn{2}{|c|}{ Kufijtë e lejuar } & \multirow{2}{*}{$\begin{array}{c}\text { Rezultatet e } \\
\text { testimit }\end{array}$} \\
\hline & & Njësia & Vlera & \\
\hline Organoleptika & $\begin{array}{c}\text { Koensistenca } \\
\text { Ngjyra } \\
\text { Era dhe Shija } \\
\text { Primesa të huja }\end{array}$ & & & \\
\hline Yndyra & AOAC 960.39 & $\%$ & Deri 35 & 6.47 \\
\hline Hiri & AOAC 920.153 & $\%$ & Deri 2.0 & 0.96 \\
\hline Nitritet & AOAC 973.31 & $\mathrm{mg} / \mathrm{kg}$ & $50-150$ & 25 \\
\hline Kripa & AOAC 935.47 & $\%$ & Deri 5.0 & 2.00 \\
\hline Protetinat & AOAC 981.10 & $\%$ & Deri 22 & 10.69 \\
\hline$\%$ e $\mathrm{H} 2 \mathrm{O}$ & AOAC 950.46 & $\%$ & Deri 65 & 59.74 \\
\hline
\end{tabular}

Tabela 1. Analiza fiziko - kimike të parizier pule $400 \mathrm{gr}$.

Bazuar në rezultatet e fituara gjatë analizës fiziko - kimike të parizer pule 400 gr. të cilat rezultate janë të paraqitura në tabelen 1, vërejmë se sa i përket analizave organoleptike (koensistenca, era, shija dhe primesa të huaja), bazuar në metodat standarde, parizer pule 400 gr është në rregull dhe posedon veti organoleptike të rregullta.

Per sa i përket përbërjes kimike rezulton:

- Yndyra është në vlerë prej $6.47 \%$ (sasia e lejuar $35 \%$ );

- Hiri është në vlerë prej $0.96 \%$ (sasia e lejuar deri 2);

- Nitritet janë në vlerë prej 23 mg/kg (sasia e lejuar 50 - 150); 
- Proteinat në vlerë prej $10.69 \%$ (sasia e lejuar deri 22);

- \% e H2O në vlerë prej $59.74 \%$ (sasia e lejuar deri 65);

Bazuar në rezultatet e fituara gjatë analizës fiziko - kimike të parizer pule $400 \mathrm{gr}$. të cilat rezultate janë të paraqitura në tabelën 1, vërejmë se sa i përket analizave kimike të gjithë parametra janë në kuadër të sasisë së lejuar ligjore.

\subsubsection{Rezultatet e analizave mikrobiologjike}

\begin{tabular}{|l|c|c|c|c|}
\hline \multicolumn{1}{|c|}{ Parametrat e testuar } & Metoda standarde & $\begin{array}{c}\text { Sasia e } \\
\text { mostrës } \\
\text { gr (ml) }\end{array}$ & $\begin{array}{c}\text { Kufijtë e } \\
\text { lejuar } \\
\text { cfu gr/ml }\end{array}$ & $\begin{array}{c}\text { Rezultatet e } \\
\text { testimit cfu } \\
\text { gr/ml }\end{array}$ \\
\hline Salmonella & ISO 6579:2002 & 25 & 0 & $\begin{array}{c}\text { Nuk janë } \\
\text { gjetur }\end{array}$ \\
\hline Staphylococcus aureus & ISO 6888-2:1999 & 0,01 & 0 & $\begin{array}{c}\text { Nuk janë } \\
\text { gjetur }\end{array}$ \\
\hline Escherichia coli & ISO 16649-2:2001 & 0,01 & 0 & $\begin{array}{c}\text { Nuk janë } \\
\text { gjetur }\end{array}$ \\
\hline Bakteret koliforme & ISO 4832-2006 & 0,01 & 0 & $\begin{array}{c}\text { Nuk janë } \\
\text { gjetur }\end{array}$ \\
\hline Tharmi dhe myshqet & & 1 & & $\begin{array}{c}<10 \mathrm{cfu} \\
\text { gr/ml }\end{array}$ \\
\hline $\begin{array}{l}\text { Numri i përgjithshëm i baktereve } \\
\text { të gjalla mezofile }\end{array}$ & ISO 4833:2003 & 0,01 & & \\
\hline
\end{tabular}

Tabela 2. Analizat mikroiologjike te parizer pule $400 \mathrm{gr}$.

Në bazë të tabelës së paraqiturë më lartë, rezulton të kemi këto rezultate të fituara gjatë analizës mikrobiologjike të parizer pule 400 gr:

- Salmonella - nuk janë gjetur (kufijtë e lejuar $0 \mathrm{cfu}$ gr/ml);

- Staphylococcus aureus - nuk janë gjetur (kufijtë e lejuar $0 \mathrm{cfu} \mathrm{gr} / \mathrm{ml}$ );

- Escherichia coli - nuk janë gjetur (kufijtë e lejuar $0 \mathrm{cfu} \mathrm{gr} / \mathrm{ml}$ );

- Bakteret koliforme - nuk janë gjetur (kufijtë e lejuar 0 cfu gr/ml);

- Tharmi dhe myshqet - nuk janë gjetur.

Bazuar në rezultatet e fituara gjatë analizës mikrobiolgjike të parizer pule $400 \mathrm{gr}$. të cilat rezultate janë të paraqitura në tabelën 2, vërejmë se të gjithë parametrat janë konform sasisë së lejuar ligjore apo në këtë mostre nuk u gjendën mikroorganizmat e ndaluar për këtë produkt. 


\subsubsection{Rezultatet e analizave për produktin parizier viçi $400 \mathrm{GR}$}

\subsubsection{Analizat fiziko - kimike}

\begin{tabular}{|c|c|c|c|c|}
\hline \multirow[t]{2}{*}{ Parametrat e testuar } & \multirow[t]{2}{*}{ Metoda standarde } & \multicolumn{2}{|c|}{ Kufijtë e lejuar } & \multirow{2}{*}{$\begin{array}{c}\text { Rezultatet e } \\
\text { testimit }\end{array}$} \\
\hline & & Njësia & Vlera & \\
\hline Organoleptika & $\begin{array}{c}\text { Koensistenca } \\
\text { Ngjyra } \\
\text { Era dhe Shija } \\
\text { Primesa të huja }\end{array}$ & & & \\
\hline Yndyra & AOAC 960.39 & $\%$ & Deri 35 & 7.27 \\
\hline Hiri & AOAC 920.153 & $\%$ & Deri 2.0 & 0.98 \\
\hline Nitritet & AOAC 973.31 & $\mathrm{mg} / \mathrm{kg}$ & $50-150$ & 25.0 \\
\hline Kripa & AOAC 935.47 & $\%$ & Deri 5.0 & 1.93 \\
\hline Protetinat & AOAC 981.10 & $\%$ & Deri 22 & 11.27 \\
\hline$\%$ e $\mathrm{H} 2 \mathrm{O}$ & AOAC 950.46 & $\%$ & Deri 65 & 50.25 \\
\hline
\end{tabular}

Tabela 3. Analiza fiziko kimike e parizer viçi $400 \mathrm{gr}$.

Bazuar në rezultatet e fituara gjatë analizës fiziko - kimike të parizer viçi 400 gr. të cilat rezultate janë të paraqitura në tabelën 3, vërejmë se sa i përket analizave organoleptike (koensistenca, era, shija dhe primesa të huaja), bazuar në metodat standarde, parizer viçi 400 gr është në rregull dhe posedon veti organoleptike të rregullta.

Për sa i përket përbërjes kimike rezulton:

- Yndyra është në vlerë prej $7.27 \%$ (sasia e lejuar $35 \%$ );

- Hiri është në vlerë prej 0.98 \% (sasia e lejuar deri 2);

- Nitritet janë në vlerë prej $25 \mathrm{mg} / \mathrm{kg}$ (sasia e lejuar 50 - 150);

- Proteinat në vlerë prej $11.27 \%$ (sasia e lejuar deri 22) dhe

- $\quad \%$ e H2O në vlerë prej $50.25 \%$ (sasia e lejuar deri 65);

Bazuar në rezultatet e fituara gjatë analizës fiziko - kimike të parizer viçi 400 gr. të cilat rezultate janë të paraqitura në tabelën 3, vërejmë se sa i përket analizave kimike të gjithë parametrat janë në kuadër të sasisë së lejuar ligjore. 


\subsubsection{Analizat mikrobiologjike}

\begin{tabular}{|l|c|c|c|c|}
\hline \multicolumn{1}{|c|}{ Parametrat e testuar } & Metoda standarde & $\begin{array}{c}\text { Sasia e } \\
\text { mostrës } \\
\text { gr (ml) }\end{array}$ & $\begin{array}{c}\text { Kufijtë e } \\
\text { lejuar } \\
\text { cfu gr/ml }\end{array}$ & $\begin{array}{c}\text { Rezultatet e } \\
\text { testimit cfu } \\
\text { gr/ml }\end{array}$ \\
\hline Salmonella & ISO 6579:2002 & 25 & 0 & $\begin{array}{c}\text { Nuk janë } \\
\text { gjetur }\end{array}$ \\
\hline Staphylococcus aureus & ISO 6888-2:1999 & 0,01 & 0 & $\begin{array}{c}\text { Nuk janë } \\
\text { gjetur }\end{array}$ \\
\hline Escherichia coli & ISO 16649-2:2001 & 0,01 & 0 & $\begin{array}{c}\text { Nuk janë } \\
\text { gjetur }\end{array}$ \\
\hline Bakteret koliforme & ISO 4832-2006 & 0,01 & 0 & $\begin{array}{c}\text { Nuk janë } \\
\text { gjetur }\end{array}$ \\
\hline Tharmi dhe myshqet & & & & \\
\hline $\begin{array}{l}\text { Numri i përgjithshëm i baktereve } \\
\text { të gjalla mezofile }\end{array}$ & ISO 4833:2003 & 0,01 & & $\begin{array}{c}<10 \mathrm{cfu} \\
\text { gr/ml }\end{array}$ \\
\hline
\end{tabular}

Tabela 4. analiza mikrobiologjike e parizer vici 400 gr.

Në bazë të tabelës së paraqiturë më lartë, rezulton të kemi këto rezultate të fituara gjatë analizës mikrobiologjike të parizer viçi 400 gr:

- Salmonella - nuk janë gjetur (kufijtë e lejuar 0 cfu gr/ml );

- Staphylococcus aureus - nuk janë gjetur (kufijtë e lejuar $0 \mathrm{cfu} g r / \mathrm{ml}$ );

- Escherichia coli - nuk janë gjetur (kufijtë e lejuar $0 \mathrm{cfu} \mathrm{gr} / \mathrm{ml}$ );

- Bakteret koliforme - nuk janë gjetur (kufijtë e lejuar 0 cfu gr/ml );

- Tharmi dhe myshqet - nuk janë gjetur.

Bazuar në rezultatet e fituara gjatë analizës mikrobiolgjike të parizer viçi 400 gr. të cilat rezultate janë të paraqitura në tabelën 4, vërejmë se të gjithë parametrat janë konform sasisë së lejuar ligjore apo në këtë mostre nuk u gjendën mikroorganizmat e ndaluar për këtë produkt. 


\section{KONKLUZIONE DHE REKOMANDIME}

Teknologjia e prodhimit të mishit në përgjithësi dhe teknologjia e përpunimit të sallamave në veçanti, është mjaft e zhvilluar edhe në Kosovë, ku njëra ndër kompanitë në të cilën është zhvilluar edhe hulumtimi është edhe kompania SHPK "Sole Kosova".

Si lëndë e parë për prodhimin e sallamës së gjedhit dhe të pulës duke marrë parasysh mungesën e mishit në Kosovë, zakonisht përdoret mishi i importuar i ngrirë në temperaturën - 18 gradë, i cili para se të futet në përpunim, shkrihet në temperaturën e ambientit në afro 10 gradë Celsius, në kohëzgjatje prej 12 orë.

Teknologjia e prodhimit të sallamave, në kompaninë SHPK "Sole Kosova" realizohet konform rregulloreve ligjore të cilat rregullojnë këto çështje dhe kjo mund të vërehet përmes përcjelljes së disa fazave të këtij procesi si: Bluarja e mishit realizohet në repart të posaçem dhe me makinë të destinuar për këtë qëllim, materiali i bluar (brumi) transportohet në makinën për përzierje të quajtur "kuter" ku bëhet përzierja e brumit të mishit me kripë dhe melmesat e caktuara, bazuar në recepturën e përdorurë, përmes makinës së mbushjes mbushen mbështjellësit me materialin e përzier, vendosen në furrat për tharje duke përdorë temperaturën prej $72^{\circ} \mathrm{C}$ në brendësi të produkti për një kohë 60 min si dhe ftofja në fazën pasuese në temperaturë $0-5^{\circ} \mathrm{C}$, për 12 orë dhe paketimi dhe etiketimi i produktit.

Përveç metodologjisë së përdorurë gjatë teknologjisë së prodhimit të sallamave e cila është brenda standarteve ligjore, prodhimi i sallamave realizohet përmes paisjeve adekuate të cilat përdoren për prodhimin modern dhe të sigurtë të sallamave, krahas mirëmbajtjes dhe higjenizimit të tyre.

Bazuar në rezultatet e fituara gjatë analizës organoleptike të parizer pule 400 gr. dhe parizer viçi 400 gr. rezulton se parametrat si koensistenca, era, shija dhe primesa të huaja në produket janë në suaza të vlerave normale, ndërsa sa i përket analizave kimike të parizer pule $400 \mathrm{gr}$ dhe parizer vici $400 \mathrm{gr}$ si vlerat e yndyrës, hirit, nitriteve, proteinave dhe \% se $\mathrm{H} 20$, githashtu rezultuan me vlera të lejuara, konformë rregulloreve ligjore, gjë që tregon qse sallamat e prodhuara i plotesojnë kriteret nutricionale për konsumatorin.

Bazuar në rezultatet e fituara gjatë analizës mikrobiologjike të parizer pule 400 gr.dhe parizet viçi 400 gr. rezultouan negative në praninë e mikroorganizmave si Salmonella, Staphylococcus aureus, 
Escherichia coli, bakteret koliforme, tharmi dhe myshqet, gjë që tregon që sallamat e prodhuara njëkohësisht janë të sigurta dhe nuk rrezikojnë shëndetin e konsumatorit.

Kompanitë për prodhimin e produkteve të mishit në Kosovë, duhet që të vazhdojnë që jo vetëm t'i përmbahen standardeve minimale të prodhimit por duhet që këto standarde t'i avansojnë në stad edhe më të lartë, krahas kontrollit të vazhdueshëm të institucioneve shtetrore përkatëse ndaj këtyre kompanive përmes inspeksioneve dhe analizave të rregullta të prodhimeve të tyre, sipas rregulloreve ligjore të cilat duhet të zbatohen në përpikmëri, me qellim të prodhimeve të mishit të kompletuara nën aspektin nutritiv dhe të sigurt dhe të parrezikshëm për shëndetin e konsumatorit në Kosovë. 


\section{REFERENCAT}

1. Arnau Arboix J Cooked ham. In: Jensen WK, Devine C, Dikeman M (eds) Encyclopedia of meat sciences. Elsevier Academic Press, Oxford, pp 562-566, (2004)

2. Cobiac L, Droulez V, Leppard P et al. "Use of external fat width to describe beef and lamb cuts in food composition tables" J Food Comp Anal, 16: 133-145, ( 2003)

3. Cabrera,M.C., \& Saadoun, A., An overview of the nutritionalvalue of beef and lamb meat from South America, Meat Science (2014),

4. Donnelly, Fiona. "The basic rules of sausage making," The Courier-Mail, ( 2011).

5. Gou P, Arnau J, Garcia-Gil N, Fulladosa E, Serra X Dry-cured ham. In: Hui YH (ed) Handbook of meat and meat processing. CRC Press, Boca Raton, pp 673-687, (2012)

6. Huff Lonergan E, Zhang W, Lonergan SM "Biochemistry of postmortem muscle lessons on mechanisms of meat tenderization” Meat Sci 86:184-195, (2010)

7. Food and Agriculture Organization of the United Nations. 1985. "Small-Scale Sausage Production" (1985).

8. FAO Corporate Document Repository, "Meat Processing Technology for small to mediums" (2010)'

9. Pegg RB, Shahidi F “ Processing of nitrite-free cured meats” In: Nollet LML, Toldrá F (eds) Advanced technologies for meat processing. Taylor \& Francis, Boca Raton, pp 308-327, (2006).

10. Handbook of Food Chemistry pp 471-510|, January 2014

11. Surendranath P. Suman1,* and Poulson Joseph "Myoglobin Chemistry and Meat Color" University of Kentucky, Lexington, Kentucky , Annu. Rev. Food Sci. Technol. 4:79-99, ( 2013.) 
12. Sebranek JG" Sausages and comminuted products" In: Caballero B (ed) Encyclopedia of food science and nutrition. Academic, Oxford, pp 3785-3791, (2003)

13. Toldrá F, Nip W-K, Hui YH “ Dry-fermented sausages: an overview” In: Toldrá F (ed) Handbook of fermented meat and poultry. Blackwell Publishing, Ames, pp 321-325, (2007).

14. UGA Extension Bulletin 1437 • Basics of Sausage Making; Formulation, Processing \& Safety, (2014) 


\section{SHTOJCAT}

Rezultatet e analizave fiziko - kimike për produktin parizier pule $400 \mathrm{gr}$ :

\begin{tabular}{|c|c|c|c|c|}
\hline \multirow[t]{2}{*}{ Parametrat e testuar } & \multirow[t]{2}{*}{ Metoda standarde } & \multicolumn{2}{|c|}{ Kufijtë e lejuar } & \multirow{2}{*}{$\begin{array}{c}\text { Rezultatet e } \\
\text { testimit }\end{array}$} \\
\hline & & Njësia & Vlera & \\
\hline Organoleptika & $\begin{array}{c}\text { Koensistenca } \\
\text { Ngjyra } \\
\text { Era dhe Shija } \\
\text { Primesa të huja }\end{array}$ & & & \\
\hline Yndyra & AOAC 960.39 & $\%$ & Deri 35 & 6.47 \\
\hline Hiri & AOAC 920.153 & $\%$ & Deri 2.0 & 0.96 \\
\hline Nitritet & AOAC 973.31 & $\mathrm{mg} / \mathrm{kg}$ & $50-150$ & 25 \\
\hline Kripa & AOAC 935.47 & $\%$ & Deri 5.0 & 2.00 \\
\hline Protetinat & AOAC 981.10 & $\%$ & Deri 22 & 10.69 \\
\hline$\%$ e $\mathrm{H} 2 \mathrm{O}$ & AOAC 950.46 & $\%$ & Deri 65 & 59.74 \\
\hline
\end{tabular}

Rezultatet e analizave mikrobiologjike për produktin parizier pule $400 \mathrm{gr}$ :

\begin{tabular}{|l|c|c|c|c|}
\hline \multicolumn{1}{|c|}{ Parametrat e testuar } & Metoda standarde & $\begin{array}{c}\text { Sasia e } \\
\text { mostrës } \\
\text { gr (ml) }\end{array}$ & $\begin{array}{c}\text { Kufijtë e } \\
\text { lejuar } \\
\text { cfu gr/ml }\end{array}$ & $\begin{array}{c}\text { Rezultatet e } \\
\text { testimit cfu } \\
\text { gr/ml }\end{array}$ \\
\hline Salmonella & ISO 6579:2002 & 25 & 0 & $\begin{array}{c}\text { Nuk janë } \\
\text { gjetur }\end{array}$ \\
\hline Staphylococcus aureus & ISO 6888-2:1999 & 0,01 & 0 & $\begin{array}{c}\text { Nuk janë } \\
\text { gjetur }\end{array}$ \\
\hline Escherichia coli & ISO 16649-2:2001 & 0,01 & 0 & $\begin{array}{c}\text { Nuk janë } \\
\text { gjetur }\end{array}$ \\
\hline Bakteret koliforme & ISO 4832-2006 & 0,01 & 0 & $\begin{array}{c}\text { Nuk janë } \\
\text { gjetur }\end{array}$ \\
\hline Tharmi dhe myshqet & & 1 & & $\begin{array}{c}<10 \text { cfu } \\
\text { gr/ml }\end{array}$ \\
\hline $\begin{array}{l}\text { Numri i përgjithshëm i baktereve } \\
\text { të gjalla mezofile }\end{array}$ & ISO 4833:2003 & 0,01 & & \\
\hline
\end{tabular}


Rezultatet e analizave fiziko - kimike për produktin parizier viçi $400 \mathrm{gr}$ :

\begin{tabular}{|c|c|c|c|c|}
\hline \multirow[t]{2}{*}{ Parametrat e testuar } & \multirow[t]{2}{*}{ Metoda standarde } & \multicolumn{2}{|c|}{ Kufijtë e lejuar } & \multirow{2}{*}{$\begin{array}{l}\text { Rezultatet e } \\
\text { testimit }\end{array}$} \\
\hline & & Njësia & Vlera & \\
\hline Organoleptika & $\begin{array}{c}\text { Koensistenca } \\
\text { Ngjyra } \\
\text { Era dhe Shija } \\
\text { Primesa të huja }\end{array}$ & & & \\
\hline Yndyra & AOAC 960.39 & $\%$ & Deri 35 & 7.27 \\
\hline Hiri & AOAC 920.153 & $\%$ & Deri 2.0 & 0.98 \\
\hline Nitritet & AOAC 973.31 & $\mathrm{mg} / \mathrm{kg}$ & $50-150$ & 25.0 \\
\hline Kripa & AOAC 935.47 & $\%$ & Deri 5.0 & 1.93 \\
\hline Protetinat & AOAC 981.10 & $\%$ & Deri 22 & 11.27 \\
\hline$\%$ e $\mathrm{H} 2 \mathrm{O}$ & AOAC 950.46 & $\%$ & Deri 65 & 50.25 \\
\hline
\end{tabular}

Rezultatet e analizave mikrobiologjike për produktin parizier viçi $400 \mathrm{gr}$ :

\begin{tabular}{|l|c|c|c|c|}
\hline \multicolumn{1}{|c|}{ Parametrat e testuar } & Metoda standarde & $\begin{array}{c}\text { Sasia e } \\
\text { mostrës } \\
\text { gr (ml) }\end{array}$ & $\begin{array}{c}\text { Kufijtë e } \\
\text { lejuar } \\
\text { cfu gr/ml }\end{array}$ & $\begin{array}{c}\text { Rezultatet e } \\
\text { testimit cfu } \\
\text { gr/ml }\end{array}$ \\
\hline Salmonella & ISO 6579:2002 & 25 & 0 & $\begin{array}{c}\text { Nuk janë } \\
\text { gjetur }\end{array}$ \\
\hline Staphylococcus aureus & ISO 6888-2:1999 & 0,01 & 0 & $\begin{array}{c}\text { Nuk janë } \\
\text { gjetur }\end{array}$ \\
\hline Escherichia coli & ISO 16649-2:2001 & 0,01 & 0 & $\begin{array}{c}\text { Nuk janë } \\
\text { gjetur }\end{array}$ \\
\hline Bakteret koliforme & ISO 4832-2006 & 0,01 & 0 & $\begin{array}{c}\text { Nuk janë } \\
\text { gjetur }\end{array}$ \\
\hline Tharmi dhe myshqet & & & & \\
\hline $\begin{array}{l}\text { Numri i përgjithshëm i baktereve } \\
\text { të gjalla mezofile }\end{array}$ & ISO 4833:2003 & 0,01 & & $\begin{array}{c}<10 \mathrm{cfu} \\
\text { gr/ml }\end{array}$ \\
\hline
\end{tabular}

